Feasibility Study of Economics and Performance of Solar Photovoltaics in Nitro, West Virginia

A Study Prepared in Partnership with the Environmental Protection Agency for the RE-Powering America's Land Initiative: Siting Renewable Energy on Potentially Contaminated Land and Mine Sites

Lars Lisell and Gail Mosey 


\section{Feasibility Study of Economics and Performance of Solar Photovoltaics in Nitro, West Virginia}

A Study Prepared in Partnership with the Environmental Protection Agency for the RE-Powering America's Land Initiative: Siting Renewable Energy on Potentially Contaminated Land and Mine Sites

Lars Lisell and Gail Mosey

Prepared under Task No. WFD3.1000

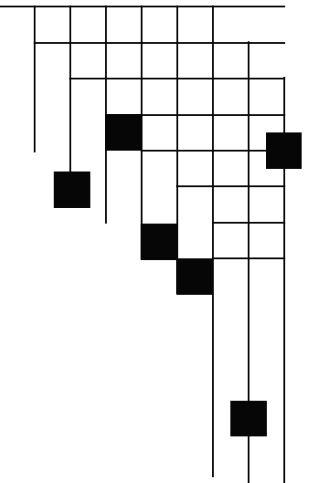




\section{NOTICE}

This report was prepared as an account of work sponsored by an agency of the United States government. Neither the United States government nor any agency thereof, nor any of their employees, makes any warranty, express or implied, or assumes any legal liability or responsibility for the accuracy, completeness, or usefulness of any information, apparatus, product, or process disclosed, or represents that its use would not infringe privately owned rights. Reference herein to any specific commercial product, process, or service by trade name, trademark, manufacturer, or otherwise does not necessarily constitute or imply its endorsement, recommendation, or favoring by the United States government or any agency thereof. The views and opinions of authors expressed herein do not necessarily state or reflect those of the United States government or any agency thereof.

Available electronically at http://www.osti.gov/bridge

Available for a processing fee to U.S. Department of Energy and its contractors, in paper, from:

U.S. Department of Energy

Office of Scientific and Technical Information

P.O. Box 62

Oak Ridge, TN 37831-0062

phone: 865.576 .8401

fax: 865.576 .5728

email: mailto:reports@adonis.osti.gov

Available for sale to the public, in paper, from:

U.S. Department of Commerce

National Technical Information Service

5285 Port Royal Road

Springfield, VA 22161

phone: 800.553.6847

fax: 703.605.6900

email: orders@ntis.fedworld.gov

online ordering: http://www.ntis.gov/ordering.htm 


\section{Executive Summary}

The U.S. Environmental Protection Agency (EPA), in accordance with the RE-Powering America's Land initiative, selected the Nitro, West Virginia area for a feasibility study of renewables on several brownfield sites. Citizens of Nitro, city planners, and site managers are interested in redevelopment uses for brownfields in Nitro, and the site is particularly well suited for solar photovoltaic (PV) installation. The purpose of this report is to assess the sites designated by the City of Nitro for possible solar PV installation and to estimate the cost, performance and site impacts of three different PV options: crystalline silicon (fixed-tilt), crystalline silicon (single-axis tracking), and thin film (fixed-tilt). Each option represents a standalone system that can be sized to use an entire available site area. In addition, the report outlines financing options that could assist in the implementation of a system.

Eight sites in or near Nitro were considered, all of which were found suitable for PV systems. The economics of the potential systems were analyzed using an electric rate of $\$ 0.08 / \mathrm{kWh}$, as well as incentives that are offered by the State of West Virginia and by the serving utility, American Electric Power (AEP). Currently, no incentives are offered for commercial size solar power systems in West Virginia, or by AEP. Table ES-1 summarizes the system performance and economics of a potential system that would use all available areas that were surveyed in Nitro. It should be noted that not all sites would need to be developed; beginning with a smaller demonstration system and increasing capacity as funds become available may make more sense. Calculations for this analysis assume the $30 \%$ federal tax credit incentive would be captured for the system.

If the electrical rate increases $43 \%$ over the next three years as anticipated, the cost of electricity would increase from $\$ 0.08 / \mathrm{kWh}$ to $\$ 0.123 / \mathrm{kWh}$. A rate increase of this magnitude would greatly improve the economics of a solar PV generation plant. Table ES-1 also summarizes the system economics with the anticipated rate increase information and job creation estimates if the Nitro location were used for PV. 
Table ES-1. PV System Performance and Economics by System Type, including Job Creation Estimates ${ }^{a}$

\begin{tabular}{|c|c|c|c|c|c|c|c|c|c|c|}
\hline \multirow[b]{2}{*}{$\begin{array}{l}\text { Array } \\
\text { Tilt } \\
\text { (Deg) }\end{array}$} & \multirow[b]{2}{*}{$\begin{array}{l}\text { PV } \\
\text { System } \\
\text { Size } \\
\text { (kW) }\end{array}$} & \multirow[b]{2}{*}{$\begin{array}{l}\text { Annual } \\
\text { Output } \\
\text { (kWh/year) }\end{array}$} & \multicolumn{2}{|c|}{$\begin{array}{c}\text { Annual Cost Savings } \\
\text { (\$/year) }\end{array}$} & \multirow[b]{2}{*}{$\begin{array}{l}\text { Annual } \\
\text { O\&M } \\
\text { (\$/year) }\end{array}$} & \multirow[b]{2}{*}{$\begin{array}{l}\text { System } \\
\text { Cost with } \\
\text { Incentives } \\
\text { (\$) }\end{array}$} & \multicolumn{2}{|c|}{$\begin{array}{l}\text { Payback Period } \\
\text { (years) }\end{array}$} & \multirow[b]{2}{*}{$\begin{array}{l}\text { Jobs }^{b} \\
\text { Created }\end{array}$} & \multirow[b]{2}{*}{$\begin{array}{l}\text { Jobs }^{c} \\
\text { Sustained }\end{array}$} \\
\hline & & & $\begin{array}{l}\text { With } \\
\text { Incentive }\end{array}$ & $\begin{array}{l}\text { With Rate } \\
\text { Increase }\end{array}$ & & & $\begin{array}{l}\text { With } \\
\text { Incentive }\end{array}$ & $\begin{array}{l}\text { With Rate } \\
\text { Increase }\end{array}$ & & \\
\hline \multicolumn{11}{|c|}{ Crystalline Silicon (Fixed-Tilt) } \\
\hline 38.4 & 27,600 & $31,408,800$ & $\$ 2,512,700$ & $\$ 3,862,654$ & $\$ 234,600$ & $\$ 96,600,000$ & 42 & 27 & 1050 & 3 \\
\hline \multicolumn{11}{|c|}{ Crystalline Silicon (Single-Axis Tracking) } \\
\hline 0 & 22,600 & $29,380,000$ & $\$ 2,350,400$ & $\$ 3,613,152$ & $\$ 474,600$ & $\$ 94,920,000$ & 51 & 30 & 1031 & 5 \\
\hline \multicolumn{11}{|c|}{ Thin Film (Fixed-Tilt) } \\
\hline 38.4 & 11,550 & $13,143,900$ & $\$ 1,051,510$ & $\$ 1,616,437$ & $\$ 86,394$ & $\$ 35,574,000$ & 37 & 23 & 387 & 1 \\
\hline
\end{tabular}




\section{Table of Contents}

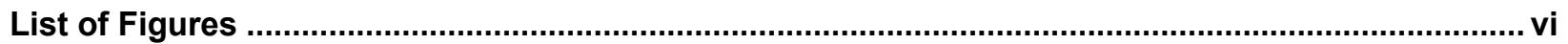

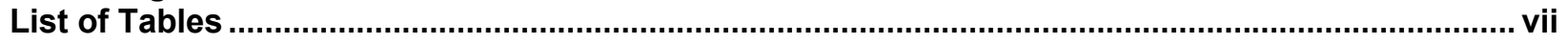

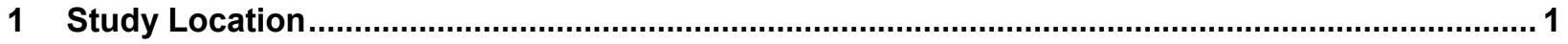

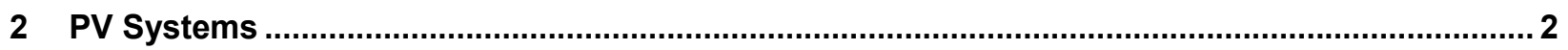

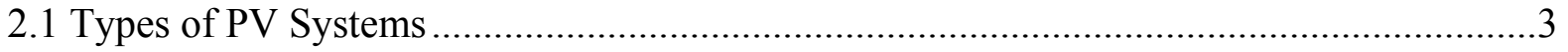

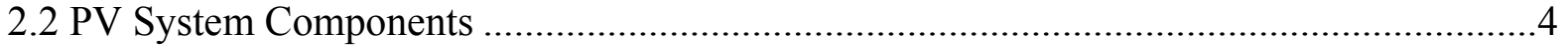

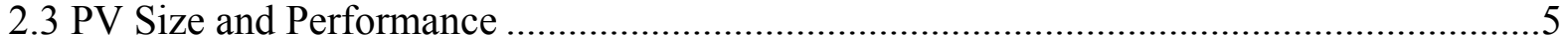

3 PV Site Locations

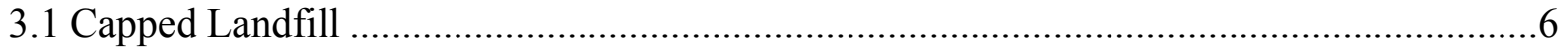

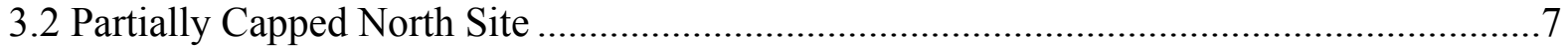

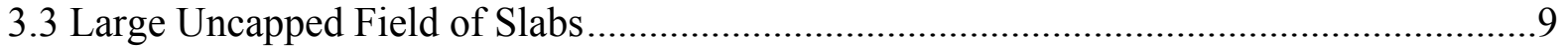

3.4 Temporarily Capped Landfill ................................................................................... 11

3.5 Temporarily Capped Small Parcel ......................................................................... 13

3.6 Temporarily Capped Small Landfill …................................................................... 15

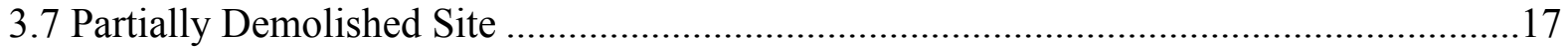

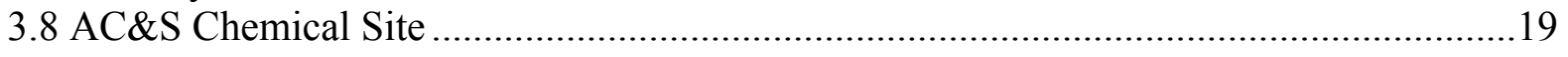

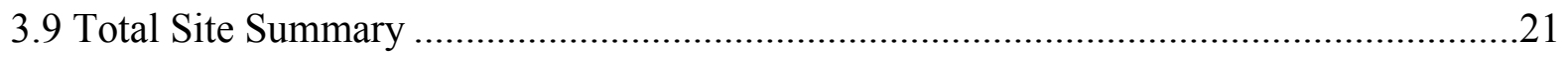

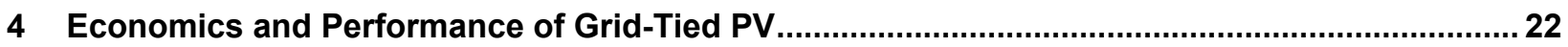

4.1 Assumptions and Input Data for Analysis ...............................................................22

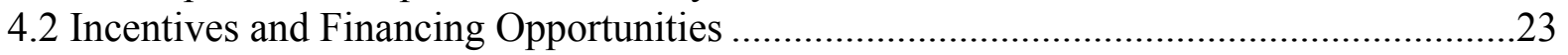

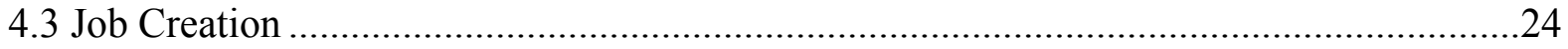

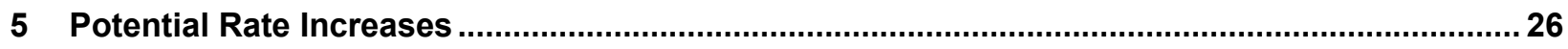

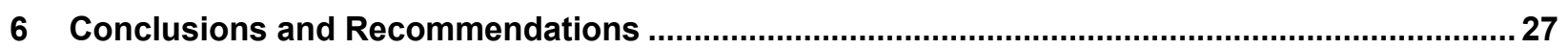

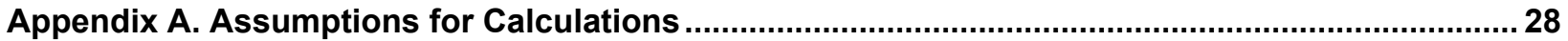

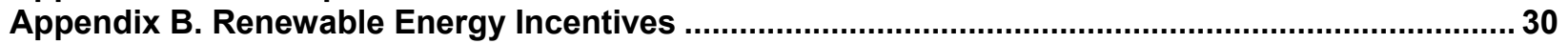




\section{List of Figures}

Figure 1. Major components of grid-connected photovoltaic system........................................... 2

Figure 2. Kanawha River capped landfill: Recommended PV system placement ........................... 6

Figure 3. Partially capped north site: Recommended PV system placement ………...................... 8

Figure 4. Partially capped north site: Ground view of recommended PV array site ...................... 9

Figure 5. Large uncapped field of slabs: Recommended PV system placement .......................... 10

Figure 6. Large uncapped field of slabs: Ground view of recommended PV array site................ 11

Figure 7. Temporarily capped landfill: Recommended PV system placement ........................... 12

Figure 8. Temporarily capped landfill: Ground view of recommended PV array site .................. 13

Figure 9. Temporarily capped small parcel: Recommended PV system placement...................... 14

Figure 10. Temporarily capped small parcel: Ground view of recommended PV array site ....... 15

Figure 11. Temporarily capped small landfill: Recommended PV system placement.................. 16

Figure 12. Temporarily capped small landfill: Ground view of recommended PV array site...... 17

Figure 13. Partially demolished site: Recommended PV system placement............................... 18

Figure 14. Partially demolished site: Ground view of recommended PV array site..................... 19

Figure 15. AC\&S Chemical Site: Recommended PV system placement ...................................... 20

Figure 16. AC\&S Chemical Site: Ground view of recommended PV array site........................... 21

Figure 17. Average installation cost for grid-tied U.S. PV systems, 2008 ................................... 22 


\section{List of Tables}

Table ES-1. PV System Performance and Economics by System Type, including Job

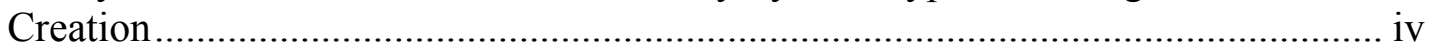

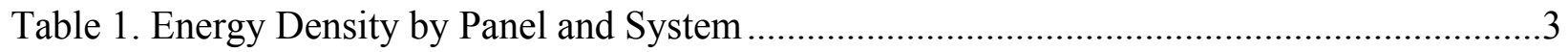

Table 2. Capped Landfill System Options ............................................................................

Table 3. Partially Capped North Site System Options.....................................................................

Table 4. Large Uncapped Field of Slabs System Options .............................................................10

Table 5. Temporarily Capped Landfill System Options ................................................................12

Table 6. Temporarily Capped Small Parcel System Options .......................................................14

Table 7. Temporarily Capped Small Landfill System Options..........................................................16

Table 8. Partially Demolished Site System Options .................................................................18

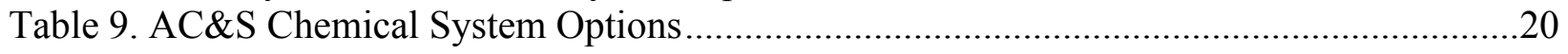

Table 10. PV System Performance and Economics by System Type...........................................21

Table 11. Estimated Job Creation by PV System Type ............................................................25

Table 12. PV System Performance and Economics with Anticipated Rate Increase .....................26

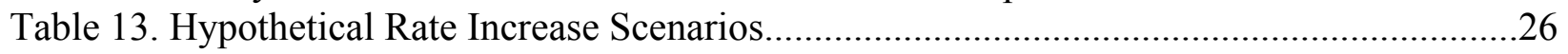

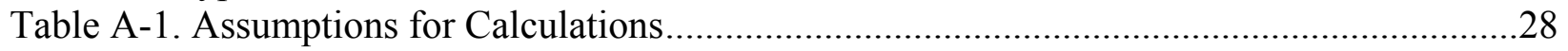

Table A-2. Other Assumptions, including Assumptions for Costs and System Types .................29

Table B-1. Brownfield Redevelopment and Renewable Energy Incentives and Financing Tools .30

Table B-2. Renewable Energy Development Incentives and Financing Tools Applicable to

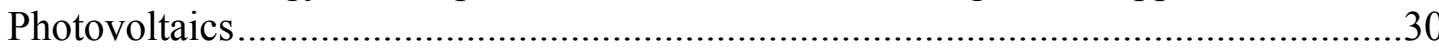

Table B-3. State Rebates for Commercial-Sector PV Projects .......................................................

Table B-4. State Tax Credits for Commercial-Sector PV Projects..................................................

Table B-5. U.S. Department of Energy Brightfields Program Grantsa ..........................................41

Table B-6. State Policy and Incentive Comparisons: Massachusetts, North Carolina, and

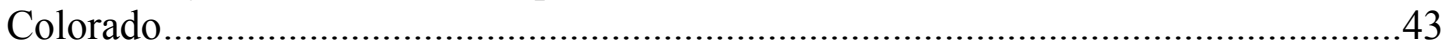

Table B-7. Key Policy Comparison for Subject States...................................................................45 


\section{Study Location}

The City of Nitro, West Virginia - the former site of multiple chemical manufacturing facilities is located outside of Charleston on the Kanawha River, with river access, rail access, and utility service to all parts of the sites identified for the solar feasibility study. Most of the chemical manufacturing companies have left the area, vacating facilities and leaving behind "brownfields." 1 Several studies are in progress to determine the extent of contamination and redevelopment potential of the brownfield sites. Some of them have been cleared of buildings and equipment, while others still have a significant amount of deserted on-site infrastructure.

Several owners of the sites have been identified, and they hold liability for site cleanup. These companies have been cooperative with clean up and redevelopment efforts in varying degrees, depending on the contamination level of the site, the cost of contamination mitigation, and the proposed reuse of the site. The sites visited by the NREL assessment team on December 12, 2009 have been designated as brownfield sites by the EPA. The eight sites identified during the site visit as areas of interest for the feasibility study are discussed below in Section 3. Some of these sites are scheduled to be permanently capped, although the timeline for capping is indefinite.

\footnotetext{
${ }^{1}$ According to the EPA Web site, brownfields are "real property, the expansion, redevelopment, or reuse of which may be complicated by the presence or potential presence of a hazardous substance, pollutant, or contaminant." For more information, see http://www.epa.gov/brownfields/.
} 


\section{PV Systems}

Solar photovoltaics (PV) are semiconductor devices that convert sunlight directly into electricity. They do so without any moving parts and without generating any noise or pollution. They must be mounted in an unshaded location; rooftops, carports and ground-mounted arrays are common mounting locations. PV systems work very well in Nitro, West Virginia, where the average global horizontal annual solar resource is $4.35-4.9 \mathrm{kWh} / \mathrm{m} 2 /$ day. This number, however, is not the amount of energy that can be produced by a PV panel. The amount of energy produced by a panel depends on the several factors. These factors include the type of collector, the tilt and azimuth of the collector, the temperature, the level of sunlight and weather conditions. An inverter is required to convert the direct current (DC) to alternating current (AC) of the desired voltage compatible with building and utility power systems. The balance of the system consists of conductors/conduit, switches, disconnects and fuses. Grid-connected PV systems feed power into the facility's electrical system and do not include batteries.

Figure 1 shows the major components of a grid-connected PV system and illustrates how these components are interconnected in a grid-connected PV system.

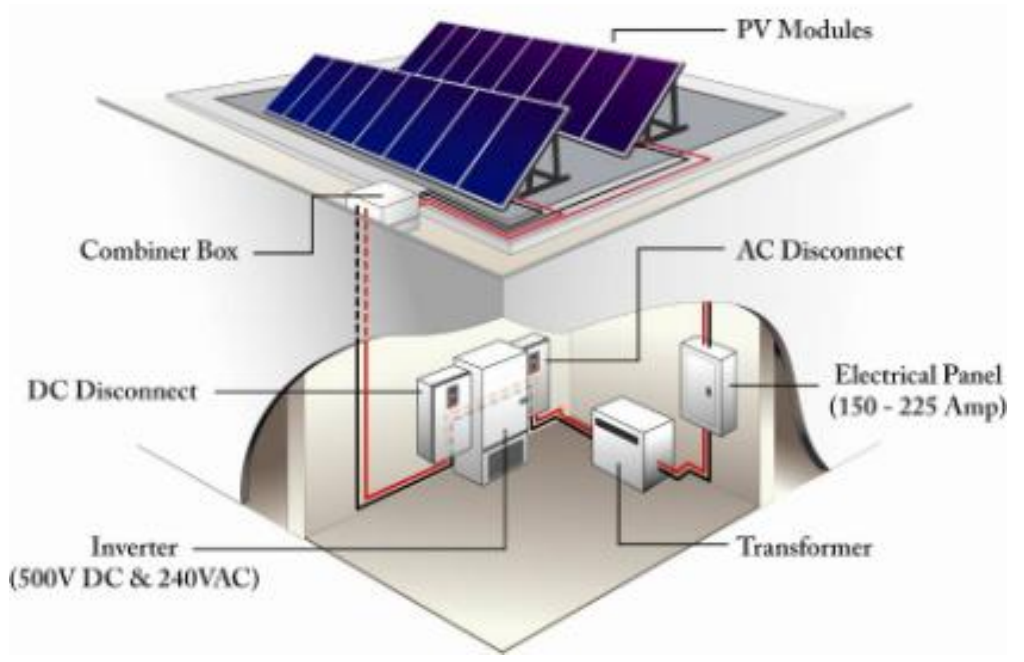

Figure 1. Major components of grid-connected photovoltaic system

PV panels are made up of many individual cells that all produce a small amount of current and voltage. These individual cells are connected in series to produce a larger current. PV panels are very sensitive to shading. When shade falls on a panel, the shaded portion of the panel cannot collect the high-energy beam radiation from the sun. If an individual cell were shaded, it would act as a resistance to the whole series circuit, impeding current flow and dissipating power rather than producing it. By determining solar access - the unimpeded ability of sunlight to reach a solar collector - one can determine whether an area is appropriate for solar panels. For this assessment, the NREL assessment team used a Solmetric solar path calculator to assess shading at particular locations by analyzing the sky view where the solar panels would be located.

If a site is found to have good solar access for a PV system, the next step is to determine the size of that system, which highly depends on the average energy use of the on-site facilities.

Providing more power than a site would use is generally not advisable due to the economics of 
most net-metering agreements. In the case of the assessed sites, all of the electricity generated at the site would be sold to the serving utility, American Electric Power (AEP), because there is no electrical load. The system size would thus be determined by the amount of electricity the electric company would be willing to purchase, or by how much land area is available. For the purposes of this report, the NREL assessment team assumed AEP would purchase any electricity that the site can generate. The systems will be broken down by site so the system size can be adjusted based on what the utility requests.

\subsection{Types of PV Systems Ground-mounted Systems}

On a \$/DC-Watt basis, ground-mounted PV systems are usually the lowest cost option. Several PV panel and mounting options are available, each having different benefits for different ground conditions. Table 1 outlines the energy density values that can be expected from each type of system.

Table 1. Energy Density by Panel and System

\begin{tabular}{lcc}
\hline System Type & $\begin{array}{l}\text { Fixed-Tilt Energy Density } \\
\text { (DC-Watts/Sq. Ft) }\end{array}$ & $\begin{array}{l}\text { Single-Axis Tracking } \\
\text { Energy Density } \\
\text { (DC-Watts/ Ft. }{ }^{2} \text { ) }\end{array}$ \\
\cline { 2 - 3 } Crystalline Silicon & 4 & 3.3 \\
Thin Film & 1.7 & 1.4 \\
Hybrid HE* & 4.8 & 3.9 \\
\hline${ }^{*}$ Because hybrid high efficiency (HE) panels do not represent a significant portion of \\
the commercial market, they were not included in the analysis. Installing panel types \\
that do not hold a significant portion of the commercial market would not be feasible for \\
a large-scale solar generation plant.
\end{tabular}

For the purposes of this analysis, all fixed-tilt systems were assumed to be mounted at latitude with a tilt of 38.4 degrees. To get the most out of the available ground area, considering whether a site layout can be improved to better incorporate a solar energy system is important. If unused structures, fences, or electrical poles can be removed, the unshaded area can be increased to incorporate more PV panels. When considering a ground-mounted system, an electrical tie in location should be identified to determine how the energy would be fed back into the grid. For this report, only fixed-tilt ground-mounted systems and single-axis tracking systems were considered.

Fixed-tilt systems are installed at a specified tilt and are fixed at that tilt for the life of the system. Single-axis tracking systems have a fixed tilt on one axis, and a variable tilt on the other axis. The system is designed to follow the sun in its path through the sky. This allows the solar radiation to strike the panel at an optimum angle for a larger part of the day than can be achieved with a fixed-tilt system. A single-axis tracking system can collect nearly $30 \%$ more electricity per capacity than can a fixed-tilt tracking system. The drawbacks include increased operations and maintenance costs, less capacity per unit area (DC-Watt/ft2), and greater installed cost (\$/DC-Watt). 


\section{Roof-mounted Systems}

In many cases, a roof is the best location for a PV system. Roof-mounted PV systems are usually more expensive than ground-mounted systems, but a roof is a convenient location because it is out of the way and is usually unshaded. Large areas with minimal rooftop equipment are preferred, but equipment can sometimes be worked around if necessary. If a building has a sloped roof, a typical flush-mounted crystalline silicon panel can achieve power densities on the order of $11 \mathrm{DC}-\mathrm{Watt} / \mathrm{ft} 2$. For buildings with flat roofs, rack-mounted systems can achieve power densities on the order of $8 \mathrm{DC}-\mathrm{Watt} / \mathrm{ft} 2$ with a crystalline silicon panel.

Typically, PV systems are installed on roofs that either are less than 5 years old or have over 30 years of life left. Because no roof area is available on the sites studied no roof-mounted analysis was conducted.

\subsection{PV System Components}

The PV system considered here has these components:

- PV arrays, which convert light energy to DC electricity

- Inverters, which convert DC to alternating current and provide important safety, monitoring and control functions

- Various wiring, mounting hardware, and combiner boxes

- Monitoring equipment

\section{PV Array}

The primary component of a PV system, the PV array, converts sunlight to electrical energy; all other components simply condition or control energy use. Most PV arrays consist of interconnected PV modules that range in size from 50 peak DC-Watts to 300 peak DC-Watts. Peak watts are the rated output of PV modules at standard operating conditions of $25^{\circ} \mathrm{C}(77 \mathrm{~F})$ and insolation of $1,000 \mathrm{Watts} / \mathrm{m}^{2}$. Because these standard operating conditions are nearly ideal, the actual output would be less under typical environmental conditions. PV modules are the most reliable components in any PV system. They have been engineered to withstand extreme temperatures, severe winds and impacts. ASTM E1038- $05^{2}$ subjects modules to impacts from one-inch hail balls at terminal velocity $(55 \mathrm{mph})$ at various parts of the module. PV modules have a life expectancy of 20-30 years, and manufacturers warranty them against power degradation for 25 years. The array is usually the most expensive component of a PV system; it accounts for approximately two-thirds the cost of a grid-connected system. A large choice of PV manufacturers is available. ${ }^{3}$

\footnotetext{
${ }^{2}$ ASTM Standard E1038, 2005, "Standard Test Method for Determining Resistance of Photovoltaic Modules to Hail by Impact with Propelled Ice Balls ," ASTM International, West Conshohocken, PA, 2005, DOI: 10.1520/E1038-05. http://www.astm.org/Standards/E1038.htm

${ }^{3}$ Go Solar California, a joint effort of the California Energy Commission and the California Public Utilities Commission, provides consumer information for solar energy systems. See http://www.gosolarcalifornia.org/ equipment/pvmodule.php.
} 


\section{Inverters}

PV arrays provide direct current power at a voltage that depends on the configuration of the array. This power is converted to alternating current at the required voltage and number of phases by the inverter. Inverters enable the operation of commonly used equipment such as appliances, computers, office equipment and motors. Current inverter technology provides true sine wave power at a quality often better than that of the serving utility. The locations of both the inverter and the balance of the system equipment are important. Inverters are available that include most or all of the control systems required for operation, including some metering and data-logging capability. Inverters must provide several operational and safety functions for interconnection with the utility system. The Institute of Electrical and Electronic Engineers, Inc (IEEE) maintains standard "P929 Recommended Practice for Utility Interface of Photovoltaic $(P V)$ Systems," which allows manufacturers to write "Utility-Interactive" on the listing label if an inverter meets the requirements of frequency and voltage limits, power quality, and nonislanding inverter testing. Underwriters Laboratory maintains "UL Standard 1741, Standard for Static Inverters and Charge Controllers for Use in Photovoltaic Power Systems, "5 which incorporates the testing required by IEEE 929 and includes design (type) testing and production testing. A large choice of inverter manufacturers is available. ${ }^{6}$

\section{Operation and Maintenance (O\&M)}

The PV panels come with a 25-year performance warranty. The inverters, which come standard with a five-year or ten-year warranty (extended warranties available), would be expected to last 10-15 years. System performance should be verified on a vendor provided web site. Wire and rack connections should be checked. For this economic analysis, an annual O\&M cost of $0.17 \%$ of total installed cost is used based on O\&M cost of other fixed-tilt grid tied PV systems. For the case of single-axis tracking, an annual O\&M cost of $0.35 \%$ of total installed cost is used based on existing single-axis tracking systems O\&M.

\subsection{PV Size and Performance}

The PV arrays must be installed in unshaded locations on the ground or on building roofs that have an expected life of at least 25 years. For this assessment, the predicted array performance was found using PVWatts ${ }^{\mathrm{TM}}$-a performance calculator for grid-connected PV systems created by NREL's Renewable Resource Data Center. ${ }^{7}$ The performance data was used to calculate the amount of revenue could be expected each year. The project economics were based on this analysis and the calculations can be found in Appendix A.

\footnotetext{
${ }^{4}$ ANSI/IEEE Std 929-1988 IEEE Recommended Practice for Utility Interface of Residential and Intermediate Photovoltaic (PV) Systems (http://standards.ieee.org/reading/ieee/std_public/description/powergen/9291988 desc.html)

${ }^{5}$ Inverters, Converters, Controllers and Interconnection System Equipment for Use With Distributed Energy Resources: UL 1741 (http://ulstandardsinfonet.ul.com/scopes/1741.html)

${ }^{6}$ Go Solar California approves inverters.

${ }^{7}$ http://www.nrel.gov/rredc/pvwatts/
} 


\section{PV Site Locations}

This section summarizes the findings of the NREL solar assessment site visit on December 12, 2009. All proposed system locations are shaded in blue in the figures.

\subsection{Capped Landfill}

The capped landfill site is located on the Kanawha River, adjacent to other sites that were examined during the site visit. This is the only site that has been fully and permanently capped. The cap on this site is built up 6 or 7 feet above grade. The site occupies 23.5 acres, according to measurements taken using Google Earth. The site is for sale and may be available for lease. Construction could start on this site immediately. This site would need to have a ballast-mounted system implemented, as ground disturbances are not permitted. The site was well kept and mowed at the time of the site visit. A row of trees about 50' high on the west edge along the river would require the solar array to be located approximately 50 ' from the west tree line. Otherwise, the site has no shading obstructions and would have $100 \%$ solar access. This site should be considered for a solar energy system. Electrical tie-ins exist at the building site in the northwest corner of the site, and electrical lines run along the north and south borders of the site. Assuming the usability percentage of the site to be $90 \%$, the available area is 920,150 square feet $(21.1$ acres). Table 2 outlines the PV system possibilities. The three options outline the three possible types of solar technology that could potentially be used. Each option is sized to use all available area outlined in Figure 2.

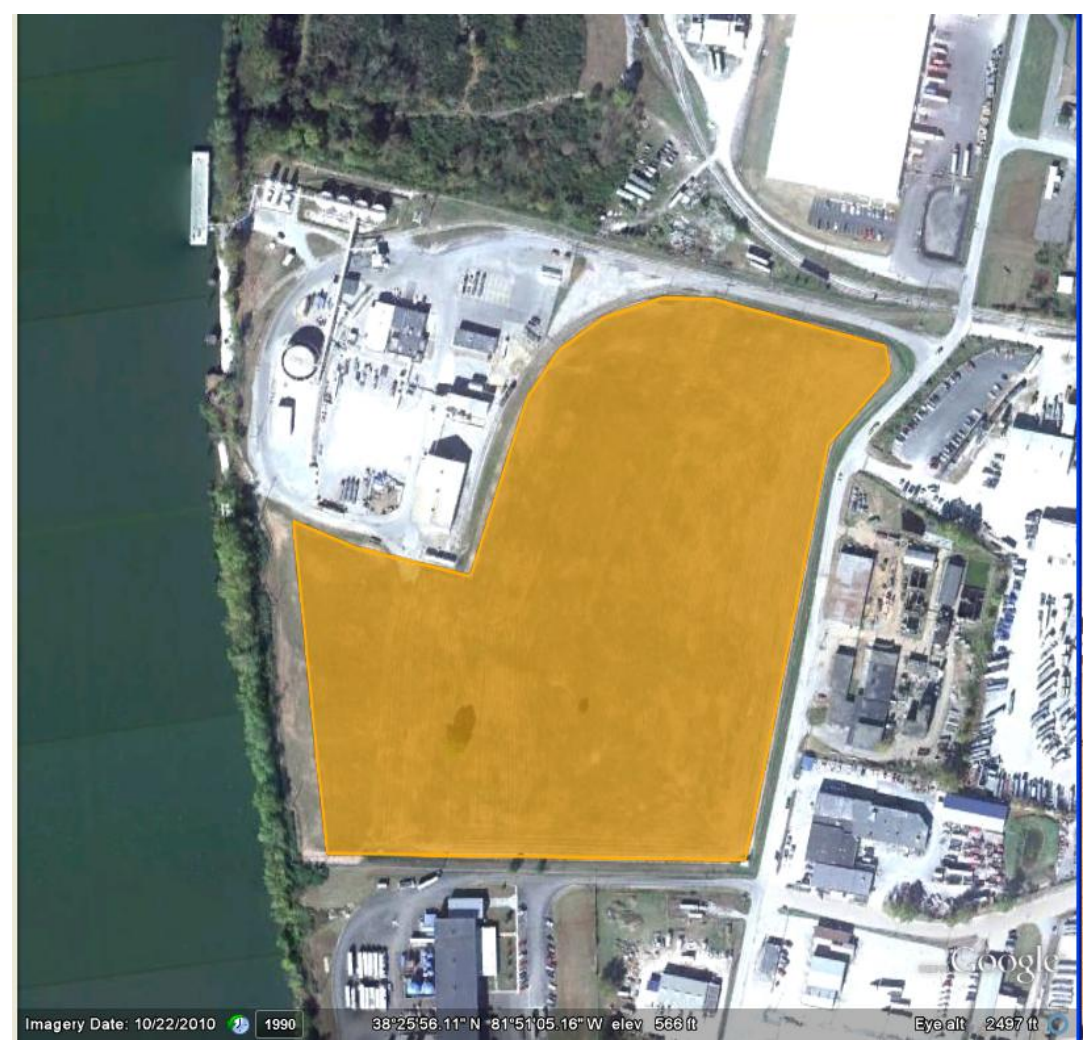

Figure 2. Kanawha River capped landfill: Recommended PV system placement

Base image courtesy of Google Earth 
Table 2. Capped Landfill System Options

\begin{tabular}{lccccc}
\hline System Type & $\begin{array}{l}\text { Potential System } \\
\text { Size (kW) }\end{array}$ & $\begin{array}{l}\text { Annual Energy } \\
\text { Output (kWh) }\end{array}$ & $\begin{array}{c}\text { Annual Cost } \\
\text { Savings (\$) }\end{array}$ & $\begin{array}{l}\text { Annual } \\
\text { O\&M (\$) }\end{array}$ & $\begin{array}{l}\text { System } \\
\text { Cost (\$) }\end{array}$ \\
\cline { 2 - 6 } $\begin{array}{l}\text { Crystalline Silicon- } \\
\text { Fixed-Tilt }\end{array}$ & 3,600 & $4,096,800$ & 327,744 & 30,600 & $12,600,000$ \\
$\begin{array}{l}\text { Crystalline Silicon- } \\
\text { Single-Axis Tracking }\end{array}$ & 3,000 & $3,900,000$ & 312,000 & 63,000 & $12,600,000$ \\
\begin{tabular}{l} 
Thin Film Fixed-Tilt \\
\hline
\end{tabular} & 1,500 & $1,707,000$ & 136,560 & 11,220 & $4,620,000$ \\
\hline
\end{tabular}

\subsection{Partially Capped North Site}

The partially capped site is located on the north side of U.S. Interstate Highway 64. This site has been partially capped. Because this site - owned by Solutia and Monsanto - is in use, it could be only partially utilized for PV installation. This site is a total of 45.3 acres, according to calculations based on drawing of the site provided to the NREL assessment team before the site visit. Of the total site area, it is estimated that $60 \%$ of the site can be utilized. Some small obstructions on the south side of the site, a row of trees approximately 40 feet from the east side of the site, and a row of trees about 50' high on the west edge along the river would require the solar array to be located approximately 50' from the tree line. Once the capping on this site is finished, a ballasted solar system would be very feasible on this site. The current state of the site would allow a usability percentage of approximately $60 \%$, leaving an available area of 1,183,960 square feet (27.1 acres). On this site, the panels would face south, presenting the potential hazard of reflecting glare from the panels at cars passing on the highway. This possibility should be assessed before a system is implemented on this site. See Table 3 for the system possibilities. The three options outline the three possible types of solar technology that could potentially be used. Each option is sized to use all available area outlined in Figure 3. Figure 4 shows a ground view of the recommended PV array placement on the partially capped north site. 


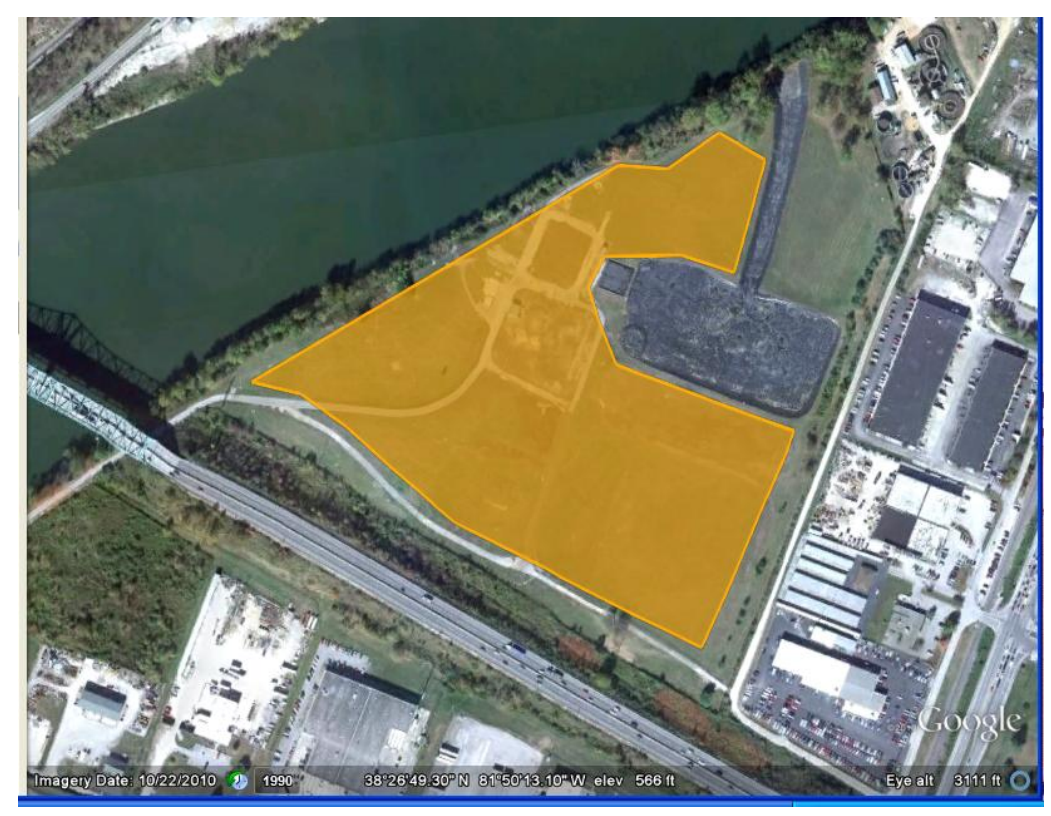

Figure 3. Partially capped north site: Recommended PV system placement Base image courtesy of Google Earth

Table 3. Partially Capped North Site System Options

\begin{tabular}{lccccc}
\hline System Type & $\begin{array}{l}\text { Potential System } \\
\text { Size (kW) }\end{array}$ & $\begin{array}{l}\text { Annual Energy } \\
\text { Output (kWh) }\end{array}$ & $\begin{array}{l}\text { Annual Cost } \\
\text { Savings (\$) }\end{array}$ & $\begin{array}{l}\text { Annual } \\
\text { O\&M (\$) }\end{array}$ & $\begin{array}{l}\text { System } \\
\text { Cost (\$) }\end{array}$ \\
\cline { 2 - 6 } $\begin{array}{l}\text { Fixed-Tilt } \\
\begin{array}{l}\text { Crystalline Silicon- } \\
\text { Single-Axis Tracking }\end{array}\end{array}$ & 4,700 & $5,348,600$ & 427,890 & 39,950 & $16,450,000$ \\
$\begin{array}{l}\text { Thin Film Fixed-Tilt } \\
\text { Thilicon- }\end{array}$ & 2,900 & $5,070,000$ & 405,600 & 81,900 & $16,380,000$ \\
\hline
\end{tabular}




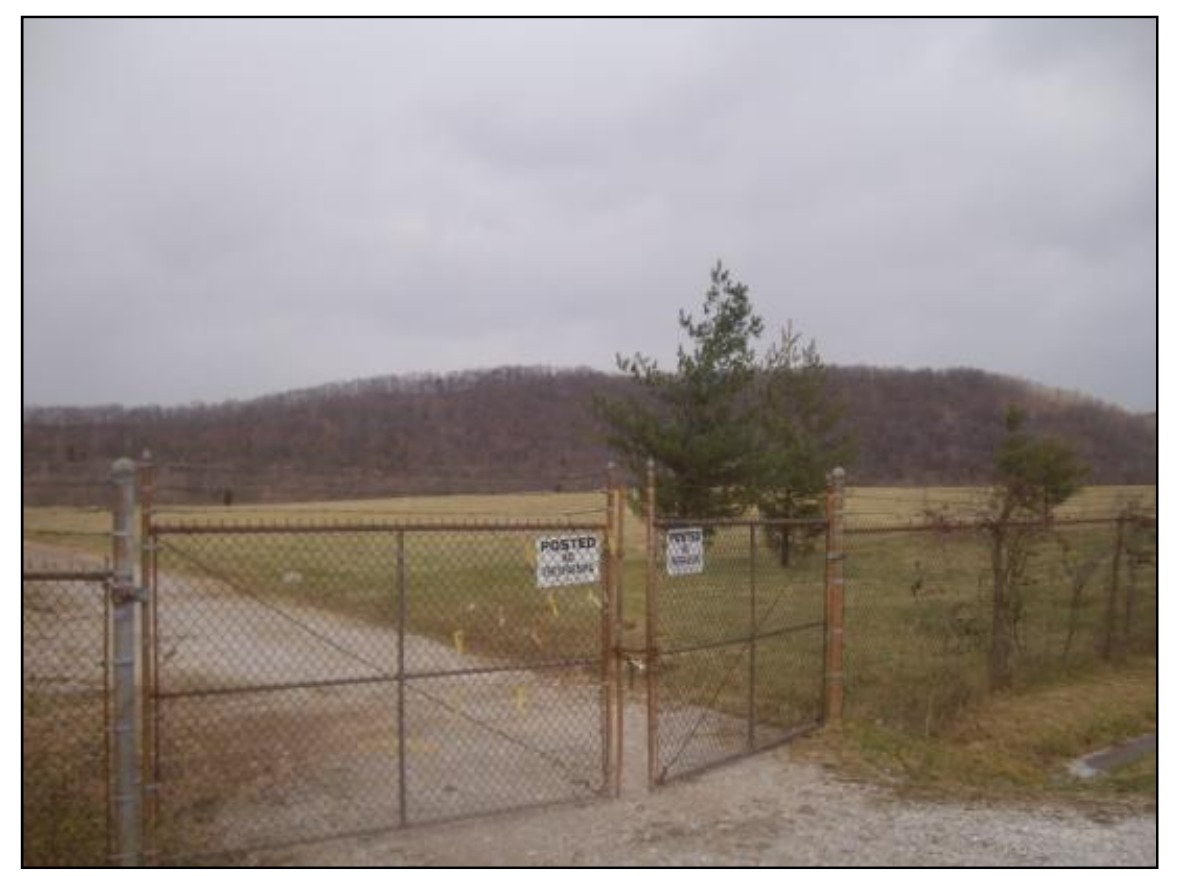

Figure 4. Partially capped north site: Ground view of recommended PV array site

Aspect: Looking Northwest

Credit: Lars Lisell, NREL

\subsection{Large Uncapped Field of Slabs}

Also bordering the Kanawha River is a large field of concrete slabs that awaits additional contamination mitigation. This site contains a series of semi-level concrete slabs that has been cleared of all infrastructure. This site occupies 71.5 acres, according to calculations based on a drawing of the site provided to the NREL assessment team before the site visit. The site has few sources of shading. A row of trees about 50' high on the west edge along the river would require the solar array to be located approximately 50 ' from the tree line. A contamination mitigation project currently underway will result in capping. In its current state or once the site is capped, it is a very feasible location for a solar system. A ballasted system would eliminate ground disturbances. Potential electrical connection points exist on the east end of the site. Solutia and Monsanto own this parcel of land. Assuming a usability percentage $90 \%$ for the site, the available area is $2,803,090$ square feet ( 64.4 acres). See Table 4 for the system possibilities. The three options outline the three possible types of solar technology that could potentially be used. Each option is sized to use all available area outlined in Figure 5. Figure 6 shows a ground view of the recommended PV array placement within the large uncapped field of slabs. 


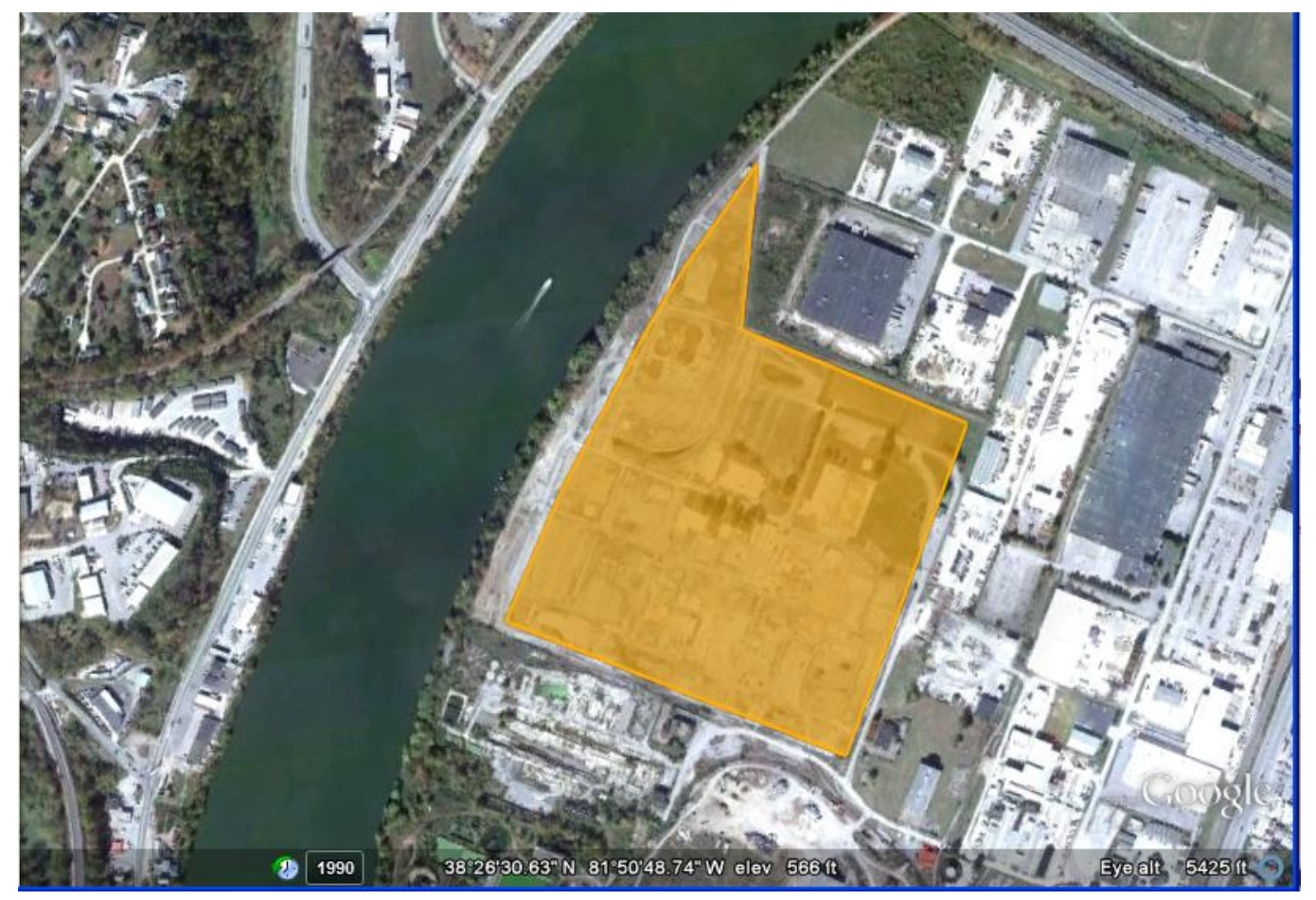

Figure 5. Large uncapped field of slabs: Recommended PV system placement Base image courtesy of Google Earth

Table 4. Large Uncapped Field of Slabs System Options

\begin{tabular}{|c|c|c|c|c|c|}
\hline System Type & $\begin{array}{l}\text { Potential System } \\
\text { Size (kW) }\end{array}$ & $\begin{array}{l}\text { Annual Energy } \\
\text { Output (kWh) }\end{array}$ & $\begin{array}{l}\text { Annual Cost } \\
\text { Savings (\$) }\end{array}$ & $\begin{array}{l}\text { Annual } \\
\text { O\&M (\$) }\end{array}$ & $\begin{array}{l}\text { System } \\
\text { Cost (\$) }\end{array}$ \\
\hline $\begin{array}{l}\text { Crystalline Silicon- } \\
\text { Fixed-Tilt }\end{array}$ & 11,200 & $12,745,600$ & $1,019,650$ & 95,200 & $39,200,000$ \\
\hline $\begin{array}{l}\text { Crystalline Silicon- } \\
\text { Single-Axis Tracking }\end{array}$ & 9,200 & $11,960,000$ & 956,800 & 193,200 & $38,640,000$ \\
\hline Thin Film Fixed-Tilt & 4,700 & $5,348,600$ & 427,890 & 35,156 & $14,476,000$ \\
\hline
\end{tabular}




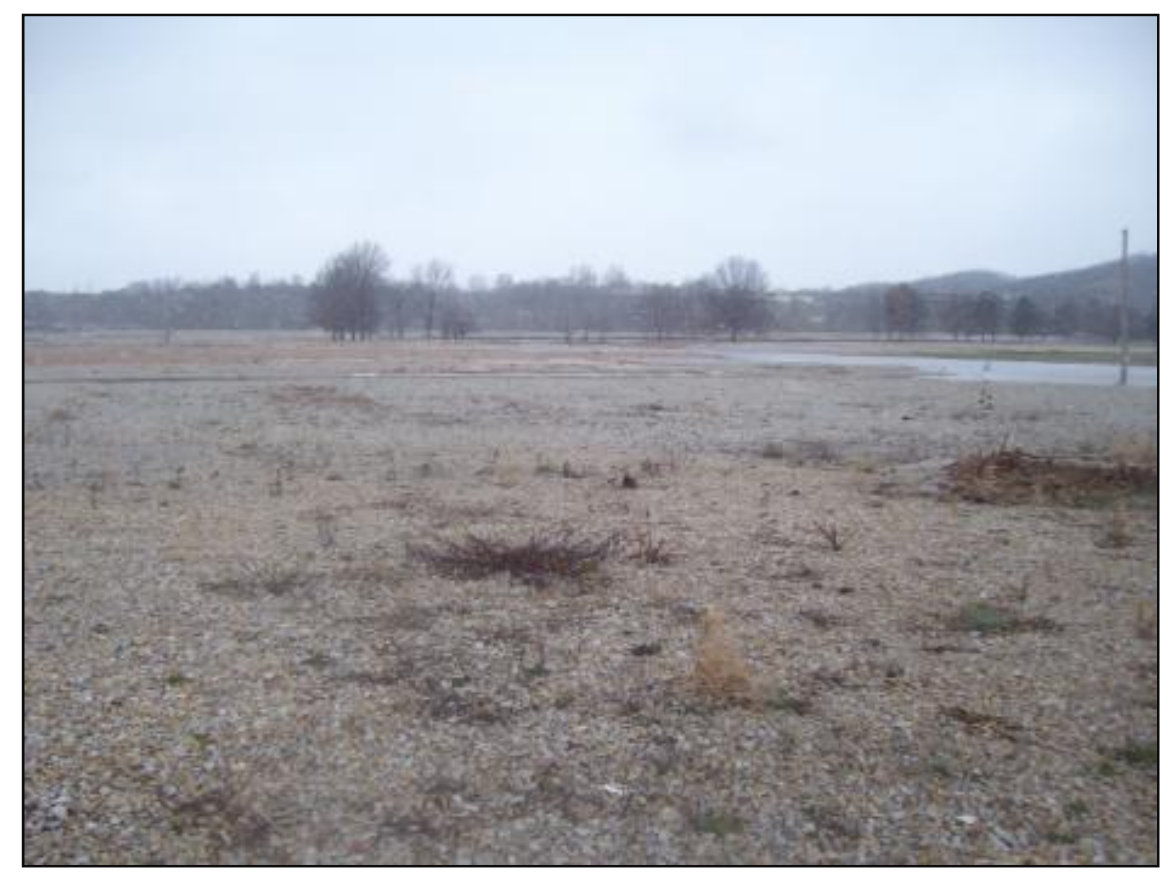

Figure 6. Large uncapped field of slabs: Ground view of recommended PV array site

Aspect: Looking West

Credit: Lars Lisell, NREL

\subsection{Temporarily Capped Landfill}

The temporarily capped landfill is an old landfill site that was covered with dirt but has not been permanently capped. This site occupies 23.8 acres, according to measurements taken using Google Earth. This site may be slated for additional contamination mitigation, including a permanent cap. The current site owner, FMC, is enrolled in a voluntary cleanup program, according to the contractor that was tasked with tracking the site cleanup. ${ }^{8}$ Before a permanent cap could be put in place, the site would need to be cleared of vegetation and leveled. If cleared, the site would provide a very feasible area for a solar energy system. A row of trees about 50' high on the west edge along the river would require the solar array to be located approximately 50 ' from the tree line. This site should be considered for a PV system once the contamination mitigation strategy has been carried out and the cleanup has been completed. Only a ballasted system should be considered due to ground disturbance restrictions on the site. Potential electrical tie-ins exist at a nearby building site. Assuming a usability percentage of $90 \%$ for the site, the available area is 933,980 square feet ( 21.4 acres). See Table 5 for the system possibilities. The three options outline the three possible types of solar technology that could potentially be used. Each option is sized to use all available area outlined in Figure 7. Figure 8 shows a ground view of the recommended placement of the PV array within the temporarily capped landfill.

\footnotetext{
${ }^{8}$ FMC Corporation is the successor to Avtex Fibers, which operated a landfill at the site.
} 


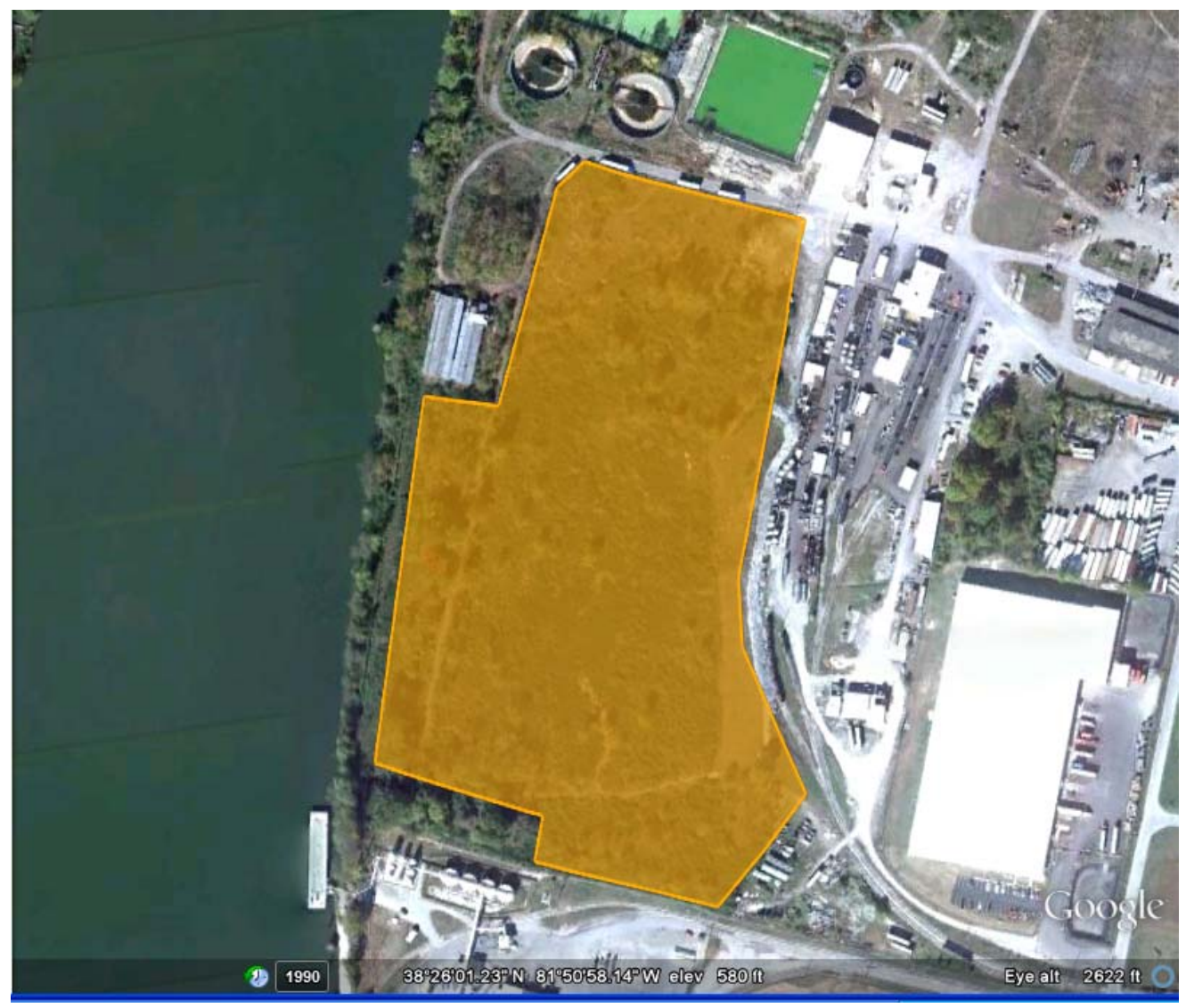

Figure 7. Temporarily capped landfill: Recommended PV system placement

Base image courtesy of Google Earth

Table 5. Temporarily Capped Landfill System Options

\begin{tabular}{|c|c|c|c|c|c|}
\hline System Type & $\begin{array}{l}\text { Potential System } \\
\text { Size (kW) }\end{array}$ & $\begin{array}{l}\text { Annual Energy } \\
\text { Output (kWh) }\end{array}$ & $\begin{array}{l}\text { Annual Cos } \\
\text { Savings (\$) }\end{array}$ & $\begin{array}{l}\text { Annual } \\
\text { O\&M (\$) }\end{array}$ & $\begin{array}{l}\text { System } \\
\text { Cost (\$) }\end{array}$ \\
\hline $\begin{array}{l}\text { Crystalline Silicon- } \\
\text { Fixed-Tilt }\end{array}$ & 3,700 & $4,210,600$ & 336,850 & 31,450 & $12,950,000$ \\
\hline $\begin{array}{l}\text { Crystalline Silicon- } \\
\text { Single-Axis Tracking }\end{array}$ & 3,000 & $3,900,000$ & 312,000 & 63,000 & $12,600,000$ \\
\hline Thin Film Fixed-Tilt & 1,500 & $1,707,000$ & 136,560 & 11,220 & $4,620,000$ \\
\hline
\end{tabular}




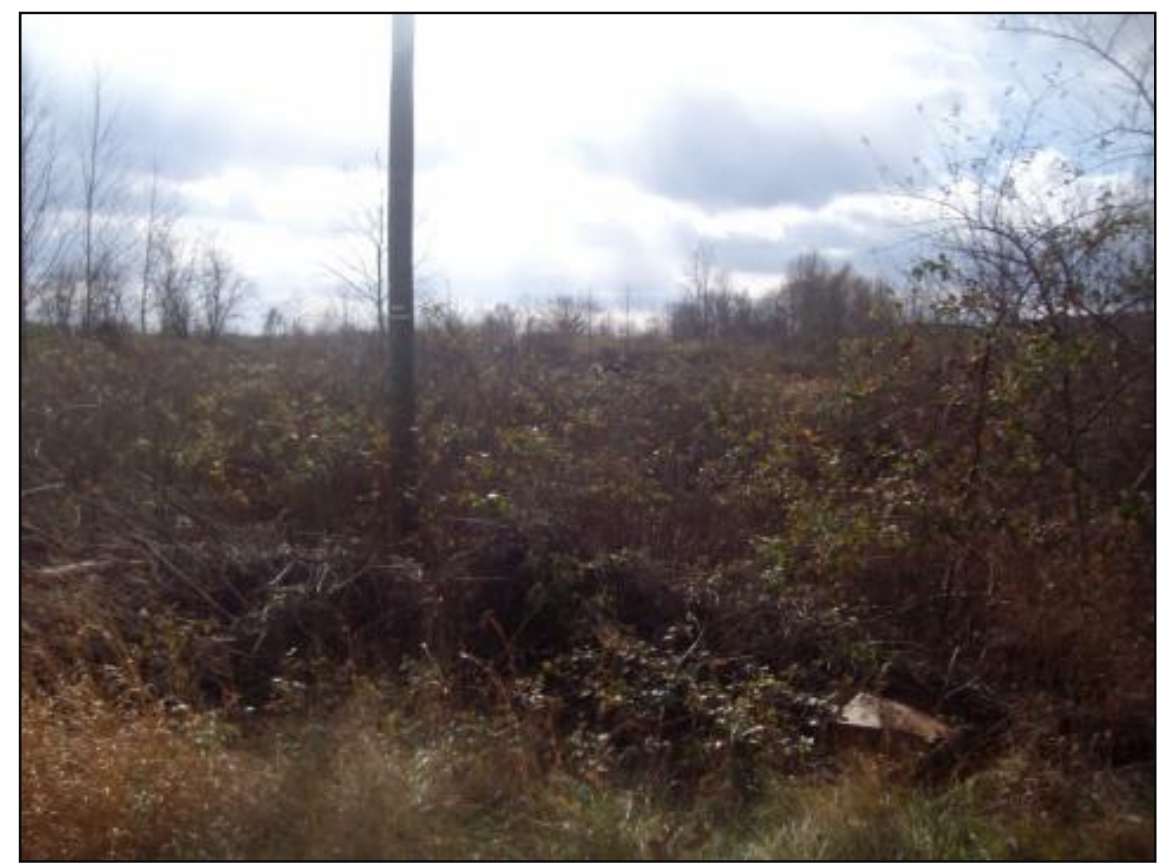

Figure 8. Temporarily capped landfill: Ground view of recommended PV array site

Aspect: Looking West

Credit: Lars Lisell, NREL

\subsection{Temporarily Capped Small Parcel}

This piece of land has a temporary cap in place. According to a prepared plan, a permanent cap will replace the temporary cap. When it is replaced, this location would provide a good site for a solar system. This site occupies 3 acres, according to calculations based on a drawing of the site provided to the NREL assessment team before to the site visit. The site has very few obstructions, one of which is the row of trees along the west side of the site along the Kanawha River. The system should be a ballasted system in order to maintain the integrity of the eventual cap. The system should be located on the east side of a small service road that is located next to the river. Potential electrical connection points exist on the east end of the site. Assuming a usability percentage of $90 \%$ for the site, the available area is 117,610 square feet ( 2.7 acres). See Table 6 for the system possibilities. The three options outline the three possible types of solar technology that could potentially be used. Each option is sized to use all available area outlined in Figure 9. Figure 10 shows a ground view of the recommended placement of the PV array on the temporarily capped small parcel. 


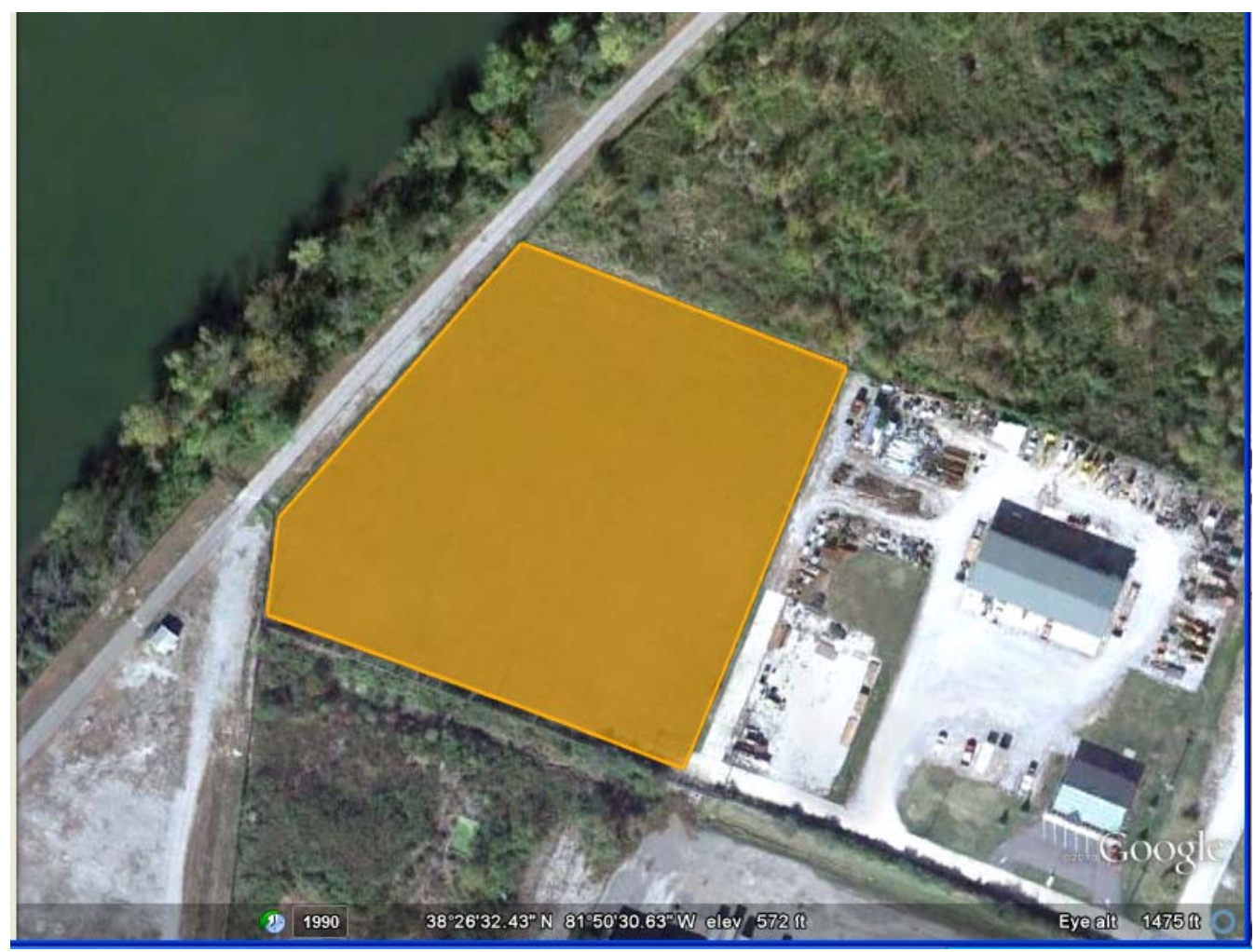

Figure 9. Temporarily capped small parcel: Recommended PV system placement Base image courtesy of Google Earth

Table 6. Temporarily Capped Small Parcel System Options

\section{System Type}

Crystalline SiliconFixed-Tilt

Crystalline SiliconSingle-Axis Tracking Thin Film Fixed-Tilt

\begin{tabular}{cccll}
$\begin{array}{l}\text { Potential System } \\
\text { Size (kW) }\end{array}$ & $\begin{array}{c}\text { Annual Energy } \\
\text { Output (kWh) }\end{array}$ & $\begin{array}{l}\text { Annual Cost } \\
\text { Savings (\$) }\end{array}$ & $\begin{array}{l}\text { Annual } \\
\text { O\&M (\$) }\end{array}$ & $\begin{array}{l}\text { System } \\
\text { Cost (\$) }\end{array}$ \\
\hline 450 & 512,100 & 40,970 & 3,825 & $1,575,000$ \\
350 & 455,000 & 36,400 & 7,350 & $1,470,000$ \\
200 & 227,600 & 18,210 & 1,496 & 616,000
\end{tabular}




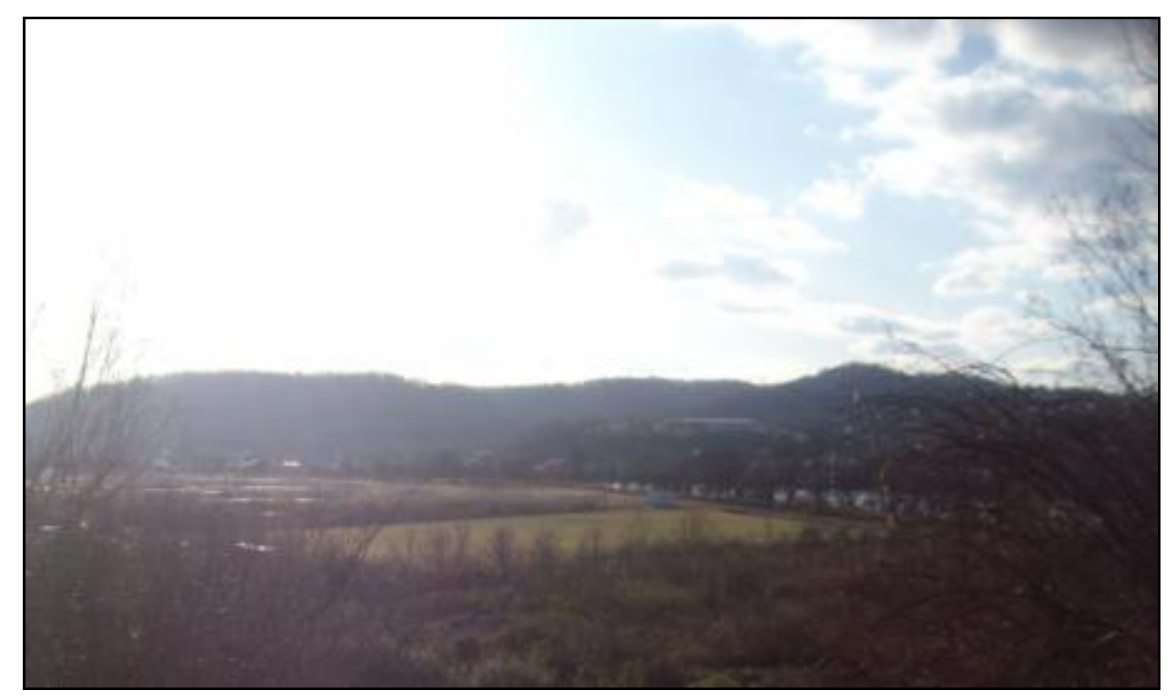

Figure 10. Temporarily capped small parcel: Ground view of recommended PV array site

Aspect: Looking South

Credit: Lars Lisell, NREL

\subsection{Temporarily Capped Small Landfill}

This area is the location of an old landfill. The landfill was covered up and has since been overgrown with brush and trees. This site is a total of 10.4 acres, calculated using a drawing of the site that was given to the assessment team prior to the site visit. Before a solar system is considered for this site, a permanent cap should be installed. With the installation of the cap, the site will be cleared of all trees and brush. A row of trees about 50' high on the west edge along the Kanawha River would require the solar array to be kept on the east side of the small service road that runs along the river. The system should be a ballasted system in order to maintain the integrity of the cap. Potential electrical connection points exist on the east end of the site. Solutia and Monsanto own this parcel of land. Assuming a usability percentage $90 \%$ for the site, the available area is 407,720 square feet $(9.4$ acres). See Table 7 for the system possibilities. The three options outline the three possible types of solar technology that could potentially be used. Each option is sized to use all available area outlined in Figure 11. Figure 12 shows a ground view of the recommended placement of the PV array on the temporarily capped small landfill. 


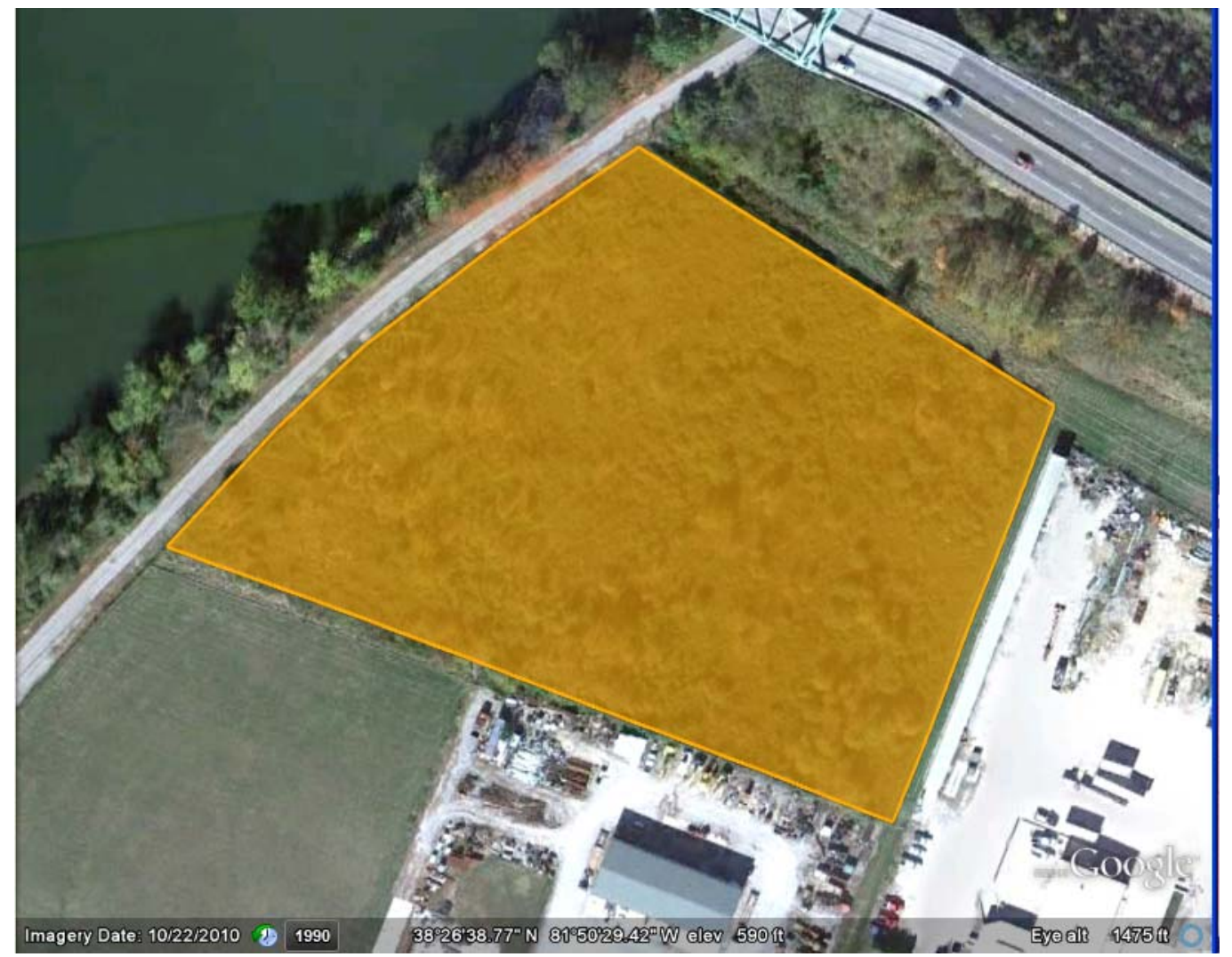

Figure 11. Temporarily capped small landfill: Recommended PV system placement Base image courtesy of Google Earth

Table 7. Temporarily Capped Small Landfill System Options

\section{System Type}

Crystalline SiliconFixed-Tilt

Crystalline SiliconSingle-Axis Tracking Thin Film Fixed-Tilt

\begin{tabular}{cccll}
$\begin{array}{l}\text { Potential System } \\
\text { Size (kW) }\end{array}$ & $\begin{array}{l}\text { Annual Energy } \\
\text { Output (kWh) }\end{array}$ & $\begin{array}{l}\text { Annual Cost } \\
\text { Savings (\$) }\end{array}$ & $\begin{array}{l}\text { Annual } \\
\text { O\&M (\$) }\end{array}$ & $\begin{array}{l}\text { System } \\
\text { Cost (\$) }\end{array}$ \\
\hline 1,600 & $1,820,800$ & 145,660 & 13,600 & $5,600,000$ \\
1,300 & $1,690,000$ & 135,200 & 27,300 & $5,460,000$ \\
650 & 739,700 & 59,180 & 4,860 & $2,002,000$ \\
\hline
\end{tabular}




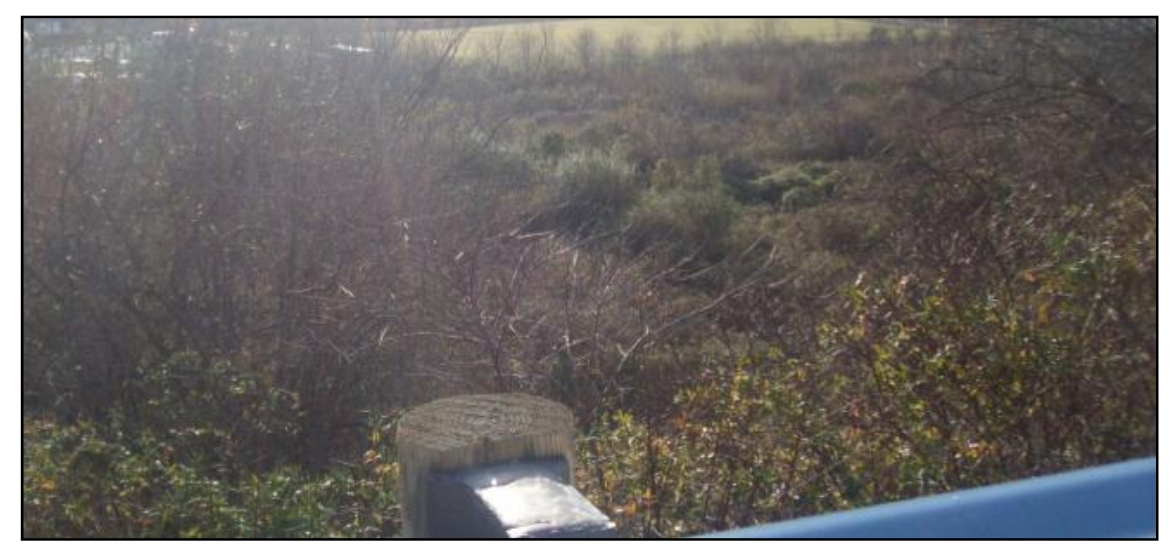

Figure 12. Temporarily capped small landfill: Ground view of recommended PV array site

Aspect: Looking South Credit: Lars Lisell, NREL

\subsection{Partially Demolished Site}

This site is a former industrial site that is partially demolished. It has been cleared of much of the infrastructure; however, a number of large and small buildings are still on the site. This site occupies 12.85 acres, according to calculations based on drawing of the site provided to the NREL assessment team before to the site visit. Where the buildings have been demolished, many concrete loading structures - approximately 3 feet in height—are still on the site. These blocks could prove to be problematic for the installation of a solar array and would need to be removed or worked around. According to the on-site staff, the remaining infrastructure is planned to be demolished. The site is going to be capped in the same manner as the capped landfill. A row of

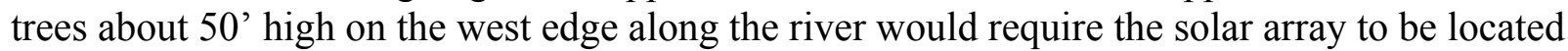
approximately 50' from the tree line. This site will be a good site for a solar system once the mitigation plan is complete. A ballasted system should be implemented at this site so that the cap is not damaged. There are electrical connection points on the east side of this site. Assuming a usability percentage of $90 \%$ for the site, the available area is 503,770 square feet ( 11.6 acres). See Table 8 for the system possibilities. The three options outline the three possible types of solar technology that could potentially be used. Each option is sized to use all available area outlined in Figure 12. Figure 14 shows a ground view of the recommended placement of the PV array on the partially demolished site. 


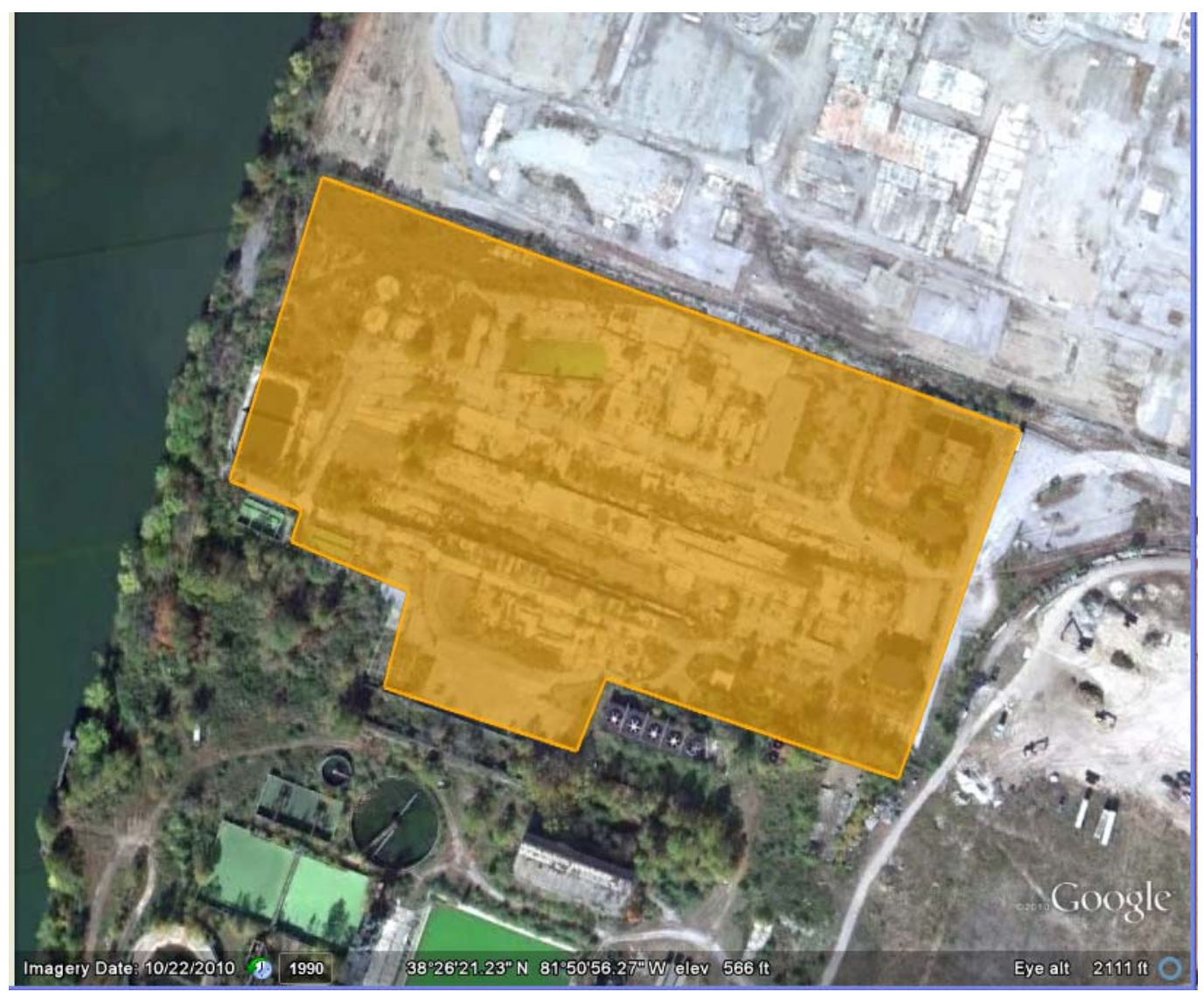

Figure 13. Partially demolished site: Recommended PV system placement Base image courtesy of Google Earth

Table 8. Partially Demolished Site System Options

\begin{tabular}{lccclc}
\hline System Type & $\begin{array}{l}\text { Potential System } \\
\text { Size (kW) }\end{array}$ & $\begin{array}{c}\text { Annual Energy } \\
\text { Output (kWh) }\end{array}$ & $\begin{array}{l}\text { Annual Cost } \\
\text { Savings (\$) }\end{array}$ & $\begin{array}{l}\text { Annual } \\
\text { O\&M (\$) }\end{array}$ & $\begin{array}{l}\text { System } \\
\text { Cost (\$) }\end{array}$ \\
\cline { 2 - 6 } $\begin{array}{l}\text { Fixed-Tilt } \\
\text { Crystalline Silicon- }\end{array}$ & 2,000 & $2,276,000$ & 182,080 & 17,000 & $7,000,000$ \\
$\begin{array}{l}\text { Single-Axis Tracking } \\
\text { Thin Film Fixed-Tilt }\end{array}$ & 1,600 & $2,080,000$ & 166,400 & 33,600 & $6,720,000$ \\
\hline
\end{tabular}




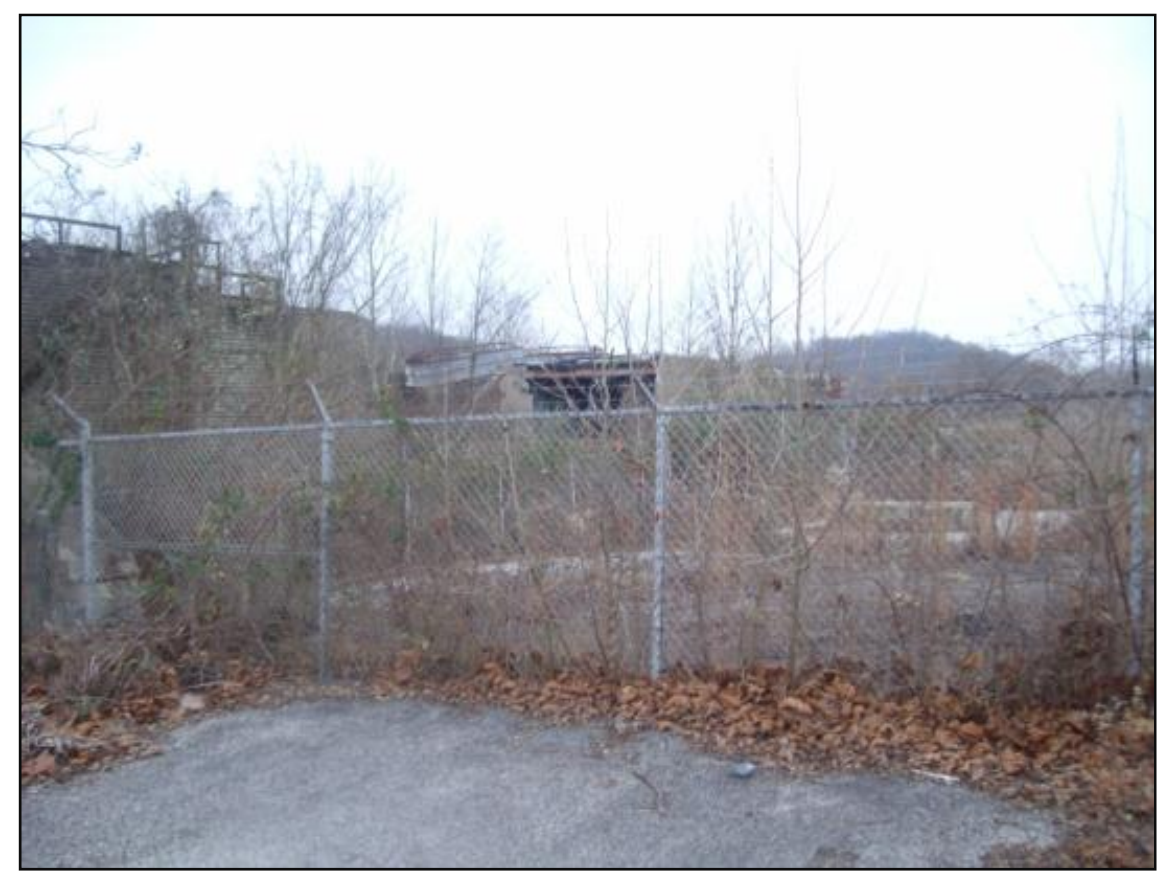

Figure 14. Partially demolished site: Ground view of recommended PV array site

Aspect: Looking Southwest

Credit: Lars Lisell, NREL

\subsection{AC\&S Chemical Site}

The final site considered is the site of the former Avtex Fibers wastewater treatment plant, which is owned by AC\&S Chemical. This site occupies 10 acres, according to calculations based on a drawing provided to the NREL assessment team during the site visit. This site has considerable infrastructure in the form of an old wastewater treatment plant. This includes large concrete holding tanks, widespread metal piping runs, and several buildings and cooling towers. One portion of the site could be used for solar with minimal site modification. This site would require an extensive cleanup to utilize the majority of the site. However, if all of the existing structures are removed, the entire site could be a suitable site for a solar PV installation. The site cleanup would also require a large number of trees and thick brush to be removed. In the current state, the site could be used to implement several small-scale solar PV systems. With minimal removal of brush and abandoned equipment, several systems on the order of $15 \mathrm{~kW}$ could implemented at various locations of the site. However, to implement a large-scale system, extensive site modification would have to occur. A row of trees about 50' high on the west edge along the river would require the solar array to be located approximately 50' from the tree line. Potential electrical connection points exist throughout the building site. Assuming a usability percentage $20 \%$ for the site, the available area is 87,120 square feet ( 2 acres). See Table 9 for the system possibilities. The three options outline the three possible types of solar technology that could potentially be used. Each option is sized to use all available area outlined in Figure 15. Figure 16 shows a ground view of the recommended placement of the PV array on the AC\&S Chemical site. 


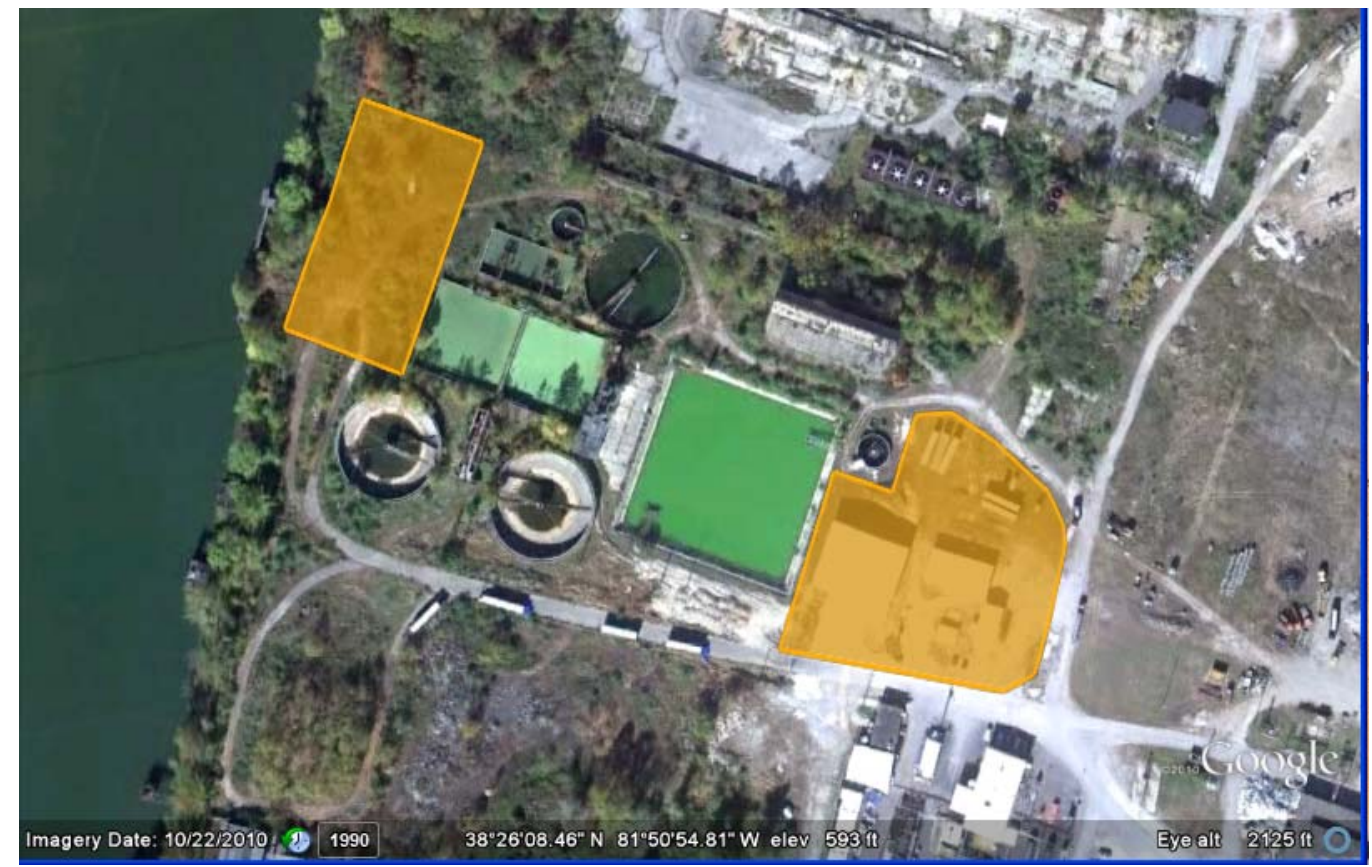

Figure 15. AC\&S Chemical Site: Recommended PV system placement

Base image courtesy of Google Earth

Table 9. AC\&S Chemical System Options

\begin{tabular}{lccccc}
\hline System Type & \multicolumn{2}{c}{$\begin{array}{l}\text { Potential System Annual Energy } \\
\text { Size (kW) }\end{array}$} & $\begin{array}{l}\text { Annual Cost } \\
\text { Output (kWh) }\end{array}$ & $\begin{array}{l}\text { Annual } \\
\text { Savings (\$) }\end{array}$ & $\begin{array}{l}\text { System } \\
\text { Cost (\$) }\end{array}$ \\
\cline { 2 - 6 } $\begin{array}{l}\text { Crystalline Silicon- } \\
\text { Fixed-Tilt }\end{array}$ & 350 & 398,300 & 31,864 & 2,975 & $1,225,000$ \\
$\begin{array}{l}\text { Crystalline Silicon- } \\
\text { Single-Axis Tracking }\end{array}$ & 250 & 325,000 & 26,000 & 5,250 & $1,050,000$ \\
\begin{tabular}{l} 
Thin Film Fixed-Tilt \\
\hline
\end{tabular} & 150 & 170,700 & 13,656 & 1,120 & 462,000 \\
\hline
\end{tabular}




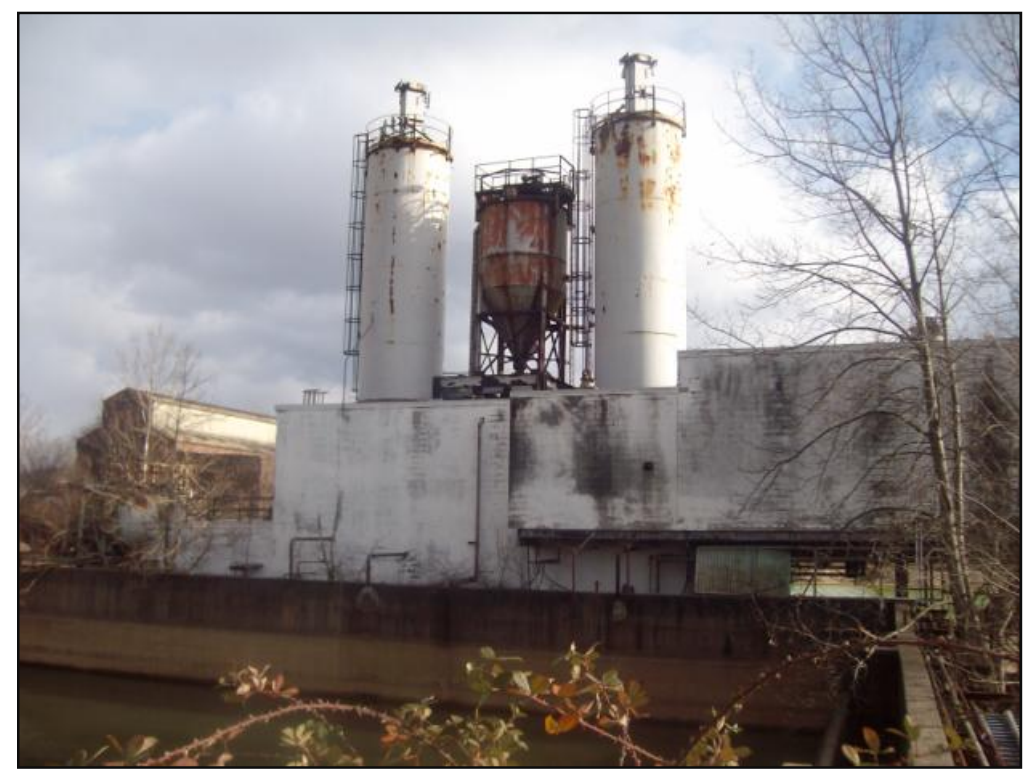

Figure 16. AC\&S Chemical Site: Ground view of recommended PV array site

Aspect: Looking Northeast

Credit: Lars Lisell, NREL

\subsection{Summary of All Sites}

Eight sites in or near Nitro were considered, all of which were found suitable for PV systems. The economics of the potential systems were analyzed using an electric rate of $\$ 0.08 / \mathrm{kWh}$, as well as incentives that are offered by the State of West Virginia and by the serving utility, American Electric Power (AEP). Currently, no incentives are offered for commercial size solar power systems in West Virginia, or by AEP. Table 10 summarizes the system performance and economics of a potential system that would use all available areas that were surveyed in Nitro. It should be noted that all sites do not need to be developed with one project; beginning with a smaller demonstration system and increasing capacity as funds become available may make more sense. Calculations for this analysis assume the $30 \%$ federal tax credit incentive would be captured for the system.

Table 10. PV System Performance and Economics by System Type ${ }^{a}$

\begin{tabular}{|c|c|c|c|c|c|c|}
\hline $\begin{array}{l}\text { Array Tilt } \\
\text { (Deg) }\end{array}$ & $\begin{array}{l}\text { PV System } \\
\text { Size (kW) }\end{array}$ & $\begin{array}{l}\text { Annual } \\
\text { Output } \\
\text { (kWh/year) }\end{array}$ & $\begin{array}{l}\text { Annual Cost } \\
\text { Savings } \\
\text { (\$/year) }\end{array}$ & $\begin{array}{l}\text { Annual } \\
\text { O\&M } \\
\text { (\$/year) }\end{array}$ & $\begin{array}{l}\text { System } \\
\text { Cost with } \\
\text { Incentives } \\
\text { (\$) }\end{array}$ & $\begin{array}{l}\text { Payback } \\
\text { Period with } \\
\text { Incentive } \\
\text { (years) }\end{array}$ \\
\hline \multicolumn{7}{|c|}{ Crystalline Silicon (Fixed-Tilt) } \\
\hline 38.4 & 27,600 & $31,408,800$ & $\$ 2,512,700$ & $\$ 234,600$ & $\$ 96,600,000$ & 42 \\
\hline \multicolumn{7}{|c|}{ Crystalline Silicon (Single-Axis Tracking) } \\
\hline 0 & 22,600 & $29,380,000$ & $\$ 2,350,400$ & $\$ 474,600$ & $\$ 94,920,000$ & 51 \\
\hline \multicolumn{7}{|c|}{ Thin Film (Fixed-Tilt) } \\
\hline 38.4 & 11,550 & $13,143,900$ & $\$ 1,051,510$ & $\$ 86,394$ & $\$ 35,574,000$ & 37 \\
\hline
\end{tabular}

${ }^{\mathrm{a}}$ Data assume a maximum usable area of $6,957,397 \mathrm{ft}^{2}$. 


\section{Economics and Performance}

\subsection{Assumptions and Input Data for Analysis}

For this analysis, the following input data were used. The installed cost of fixed-tilt, roofmounted system was assumed to be $\$ 6 / \mathrm{W}$. The installed cost of fixed-tilt, ground-mounted systems was assumed to be $\$ 5 / \mathrm{W}$. These prices include the PV array and the balance-of-system components for each system, including the inverter and electrical equipment, and installation. The economics of grid-tied PV depend on incentives, the cost of electricity, and the solar resource, including panel tilt and orientation. For this analysis, the cost of electricity was assumed to be $\$ 0.08 / \mathrm{kWh}$.

A system DC to AC conversion of $77 \%$ was assumed. This includes losses in the inverter, wire losses, PV module losses, and losses due to temperature effects, for example. Figure 17 summarizes average system installation costs for grid-tied PV systems in the United States in 2008; however, the costs have dropped significantly since 2008. PVWATTS ${ }^{\mathrm{TM}}$ was used to calculate energy performance.

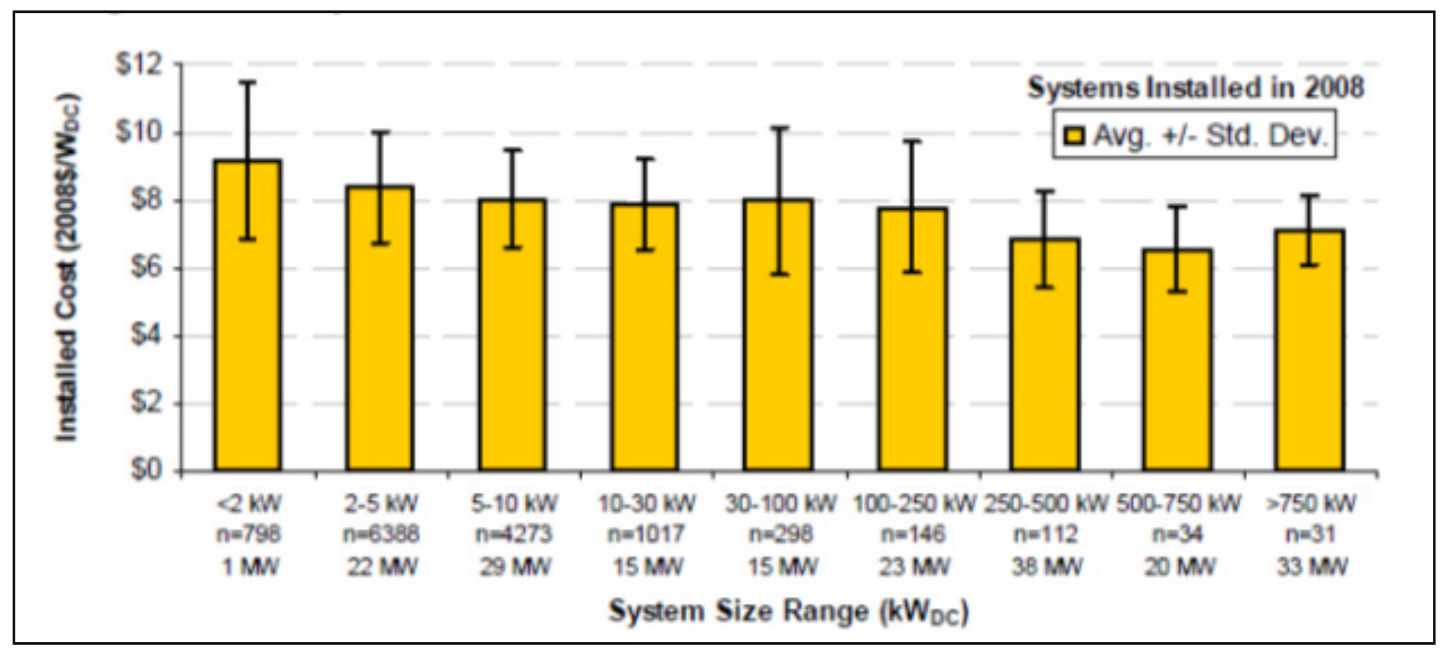

Figure 17. Average installation cost for grid-tied U.S. PV systems, $2008^{9}$

For this analysis, it is assumed that federal incentives are received. Identifying and leveraging state incentives and grants is an important part of making PV systems cost effective. A private, tax-paying entity that owns PV systems a can qualify for a $30 \%$ federal business energy investment tax credit (ITC) and accelerated depreciation on the PV system, which are worth about $15 \%$. The total potential tax benefits to the tax-paying entity are about $45 \%$ of the system cost. Alternatively, the tax-paying entity can opt to receive a cash payment of up to $30 \%$ of eligible project costs from the U.S. Department of Treasury Section 1603 program ${ }^{10}$ once the eligible system is in service. The American Reinvestment and Recovery Act (ARRA) of 2009 allows for this cash payment in lieu of the ITC. To receive the payment from Treasury, construction of the property must begin no later than December 31, 2010. Because the federal

\footnotetext{
${ }^{9}$ Wiser, R. ; Barbose, G.; Peterman, C.; Darghouth, N. (2009 October). Tracking the Sun II: The Installed Cost of Photovoltaics in the U.S. from 1998-2008. LBNL-2674E. Berkeley, CA. Lawrence Berkeley National Laboratory. http://eetd.lbl.gov/ea/emp/reports/lbnl-2674e.pdf

${ }^{10}$ This program was codified in Section 1603 of the American Recovery and Reinvestment Act of 2009.
} 
government does not pay taxes, private ownership of the PV system would be required to capture tax incentives or Section 1603 grant payments ${ }^{11}$.

\subsection{Incentives and Financing Opportunities}

The Database of State Incentives for Renewables and Efficiency (DSIRE) provides a summary of net metering, interconnection, and other incentives available to West Virginia utility customers. The utility for the City of Nitro is American Electric Power (AEP).

Renewable energy systems, including commercial solar PV, are subject to interconnection rules promulgated at the state level. No interconnection rules were found on the DSIRE Web site. The utility should be contacted directly to determine what requirements are in place. West Virginia recently released a renewable portfolio standard (RPS). It sets the goal of $25 \%$ of total electricity generation from alternative sources and renewable energy by 2025 . This standard does not have a set-aside for solar energy.

West Virginia has a net-metering policy for residential and commercial systems up to $25 \mathrm{~kW}$ in capacity that generate electricity using photovoltaics (PV), wind, biomass, landfill gas, hydropower or fuel cells. Net excess generation will be carried over to a customer-generator's next bill, for up to 12 months, as a kilowatt-hour ( $\mathrm{kWh}$ ) credit (DSIRE).

Currently, no incentives are offered by the state of West Virginia or by the serving utility, AEP. Incentives greatly affect the economics of a system, and the lack of incentives in West Virginia will have a large impact on the feasibility of a system at the sites in Nitro. The $30 \%$ tax credit federal incentive can be captured if the system is owned by a tax-paying entity.

The system facilitator could potentially pursue an agreement with AEP that would negotiate both a higher price for the electricity produced by the potential system and the potential to sell renewable energy credits (RECs). Any power that is produced by a solar PV system will help the state reach its renewable portfolio standard and would be a major opportunity for AEP to accelerate the diversification of their energy mix with clean energy. Electricity consumers in the United States are willing to pay a premium for certified clean energy, ${ }^{12}$ and AEP could start a voluntary green power-purchase pilot program with energy from the sites in Nitro. ${ }^{13}$

Technical assistance to support project development is available. Through the U.S. Department of Energy (DOE), the Office of Energy Efficiency and Renewable Energy (EERE) has funded West Virginia University and other organizations to advance the use of West Virginia's wind and renewable resources. The activity provides technical assistance to commercial power developers, technology projects involving liquid fuels developed from biomass, and information to the public on renewable energy applications. The DOE Office of EERE can assist commercial wind and

\footnotetext{
${ }^{11} \mathrm{http}: / /$ www.dsireusa.org/incentives/index.cfm?re $=1 \& \mathrm{ee}=1 \& \mathrm{spv}=0 \& \mathrm{st}=0 \& \mathrm{srp}=1 \&$ state $=\mathrm{WV}$.

12 Transmission \& Distribution World. (2009 April 14). "NREL Highlights Utility Green Power Leaders." http://tdworld.com/customer service/doe-nrel-utility-green-power-0409/. Accessed July 20, 2100.

${ }^{13}$ An example of such a program is Xcel Energy's Windsource program. For more information, see http://www .xcelenergy.com/Colorado/Company/Environment/Renewable\%20Energy/Pages/Wind Power.aspx. For detailed information about federal, state, and local incentives in West Virginia, see http://www.dsireusa.org/incentives/ index.cfm ?re $=1 \&$ ee $=1 \& \mathrm{spv}=0 \& \mathrm{st}=0 \& \mathrm{srp}=1 \&$ state $=\mathrm{WV}$.
} 
solar developers by providing detailed renewable resource maps, interfacing with West Virginia utilities and contacting local economic developers.

There are several options for financing a solar PV system. However, obtaining investment from landowners with little on-site presence - such as is the case with the sites in Nitro-can be difficult. A potential alternative financing option is the third-party ownership, power-purchase agreement (PPA). The agreement works by having a solar contractor install, finance, and operate the system, while the utility company purchase the electricity generated by the system. The system is financed by the solar contractor, and the payments are paid by the electricity and RECs that are sold to the utility. In this configuration, the land on which the PV solar system is located would need to be leased to the owner of the system for the duration of the contract.

Alternatively, the West Virginia Economic Development Authority (WVEDA) has a direct loan program that could be leveraged. Under this program, loans are set between $\$ 50$ thousand and $\$ 10$ million. Financial assistance is available to program participants for financing fixed assets for business classifications that are targeted by the West Virginia Development Office and which meet WVEDA's job creation criteria; this includes any renewable energy project. Other gap financing tools that may be available include tax increment financing (TIF) and revolving loan fund (RLF) grants from the EPA. ${ }^{14}$ Connecticut, Iowa, Michigan, and Wisconsin have been leaders in structuring state-facilitated TIF financing as an effective and efficient means to enhance brownfield programs and to obtain successful cleanup and redevelopment results. Municipalities are good candidates for TIF because it is an incentive they can implement under their own control. A full list of incentives can be found in Appendix B.

\subsection{Job Creation}

The implementation of this project would represent a large amount of money entering the clean energy industry of the United States. The Council of Economic Advisors (CEA) calculated the number of jobs (direct, indirect and induced) created due to federal spending using economic models developed with real world data. CEA found that $\$ 92,000$ in federal spending is equivalent to one job-year. This means that for every $\$ 92,000$ of Federal money that is spent, there is a job created that can be sustained for one year. See Table 11 for an estimate of job creation by system type if all eight sites studied at Nitro were used for solar PV. This project represents a large amount of money that would create a significant number of jobs. A portion of these jobs, including the installation and system maintenance jobs, will be created within the community. The jobs created column refers to the number of job-years that would be created as a result of the onetime project capital investment. This means that the jobs would be created and sustained for one year. The jobs sustained column refers to the number of jobs that would be sustained as a result of the operations and maintenance of the system. These jobs would be sustained for the life of the system, due to the annual cost to keep the system operating.

\footnotetext{
${ }^{14}$ For more information, see http://epa.gov/brownfields/rlflst.htm.
} 
Table 11. Estimated Job Creation by PV System Type

\begin{tabular}{lcc}
\hline System Type & $\begin{array}{l}\text { Jobs Created } \\
\text { (job years) }^{\text {a }}\end{array}$ & $\begin{array}{l}\text { Jobs Sustained }^{\text {b }} \\
\text { (number of jobs) }\end{array}$ \\
\cline { 2 - 3 } Crystalline Silicon (Fixed-Tilt) & 1050 & 3 \\
Crystalline Silicon (Single-Axis Tracking) & 1031 & 5 \\
Thin Film (Fixed-Tilt) & 387 & 1 \\
\hline
\end{tabular}

\footnotetext{
a Job-years created as a result of project capital investment including direct, indirect and induced jobs.

${ }^{b}$ Jobs (direct, indirect and induced) sustained as a result of operations and maintenance (O\&M) of the system.
} 


\section{Potential Rate Increases}

The economics of a potential PV system in the Nitro area depend greatly on the cost of electricity. Currently, AEP is on track to raise electric rates by $43 \%{ }^{15}$ over the next three years. This would increase the cost of electricity from $\$ 0.086 / \mathrm{kWh}$ to $\$ 0.123 / \mathrm{kWh}$. A rate increase of this magnitude would greatly improve the economics of a solar PV generation plant. See Table 12 for a summary of the system economics with the anticipated rate increase information.

Table 12. PV System Performance and Economics with Anticipated Rate Increase ${ }^{a}$

\begin{tabular}{|c|c|c|c|c|c|c|}
\hline $\begin{array}{l}\text { Array Tilt } \\
\text { (Deg) }\end{array}$ & $\begin{array}{l}\text { PV System } \\
\text { Size (kW) }\end{array}$ & $\begin{array}{l}\text { Annual } \\
\text { Output } \\
\text { (kWh/year) }\end{array}$ & $\begin{array}{l}\text { Annual Cost } \\
\text { Savings } \\
\text { (\$/year) }\end{array}$ & $\begin{array}{l}\text { Annual O\&M } \\
\text { (\$/year) }\end{array}$ & $\begin{array}{l}\text { System } \\
\text { Cost with } \\
\text { Incentives } \\
\text { (\$) }\end{array}$ & $\begin{array}{l}\text { Payback } \\
\text { Period with } \\
\text { Incentive } \\
\text { (years) }\end{array}$ \\
\hline \multicolumn{7}{|c|}{ Crystalline Silicon (Fixed-Tilt) } \\
\hline 38.4 & 27,600 & $31,408,800$ & $\$ 3,862,654$ & $\$ 234,600$ & $\$ 96,600,000$ & 27 \\
\hline \multicolumn{7}{|c|}{ Crystalline Silicon (Single-Axis Tracking) } \\
\hline 0 & 22,600 & $29,380,000$ & $\$ 3,613,152$ & $\$ 474,600$ & $\$ 94,920,000$ & 30 \\
\hline \multicolumn{7}{|c|}{ Thin Film (Fixed-Tilt) } \\
\hline 38.4 & 11,550 & $13,143,900$ & $\$ 1,616,437$ & $\$ 86,394$ & $\$ 35,574,000$ & 23 \\
\hline
\end{tabular}

${ }^{a}$ Data assume a maximum usable area of $6,957,397 \mathrm{ft}^{2}$.

It is uncertain how the rates will increase in the years following the near-term jump. Using the Solar Advisor Model that was developed at NREL, ${ }^{16}$ several rate increase scenarios were modeled to determine the economic repercussions relating to the system feasibility. The thin-film system was modeled with $5 \%, 10 \%$, and $20 \%$ rate escalation rates over the system life. The results of the analysis can be found below in Table 13. The rates reflected in the table are percent rate increases above inflation. The first two rate increase scenarios- $5 \%$ and $10 \%$ - could happen given passage of legislation limiting greenhouse gas emissions. The third rate increase scenario is less likely but not impossible.

Table 13. Hypothetical Rate Increase Scenarios

\begin{tabular}{ccc}
\hline Rate Increase (\%/yr) & Payback Period (yrs) & Net Present Value (\$) \\
\cline { 2 - 3 } $5 \%$ & 24.6 & $\$-16,254,848$ \\
$10 \%$ & 16.5 & $\$ 3,649,294$ \\
$20 \%$ & 11.1 & $\$ 176,205,055$ \\
\hline
\end{tabular}

\footnotetext{
${ }^{15}$ AllBusiness.com. (2009 March 13). “AEP Asks State for 43 Percent Rate Increase” http://www.allbusiness.com/ energy-utilities/utilities-industry-electric-power/12275763-1.html. Accessed July 20, 2010.

${ }^{16}$ The Solar Advisor Model combines a detailed performance model with several types of financing for most solar technologies. For more information, see https://www.nrel.gov/analysis/sam/.
} 


\section{Conclusions and Recommendations}

The sites considered in this report are all feasible areas in which to implement solar PV system systems. Using obtainable and accessible land that is unavailable for other purposes allows for re-use of land that would not otherwise contribute to productivity for Nitro. Installing a solar generation plant and the associated facilities on brownfields relieves "greenfields" of land use impacts. Developing solar facilities on brownfields can provide an economically viable reuse option for sites with significant cleanup costs or for sites where local economic conditions prohibit traditional reuse of the site, as is the case with Nitro. The site has existing transmission capacity, roads, industrial zoning, and all other critical infrastructure in place for PV systems.

It is recommended that the party ultimately responsible for facilitating the implementation of PV systems contact AEP and attempt to set up an agreement in which AEP would purchase the electricity generated at sites studied. According to the site production calculations, the most cost effective system in terms of return on investment is the fixed-tilt, thin-film technology. The lower cost of the system combined with the ample land available makes a thin-film system a good fit for these sites. Thin-film technology is a proven technology that can be successfully implemented with a ballasted-style mounting system. Crystalline silicon system styles-both fixed-tilt tracking and single-axis tracking systems - could also be implemented, but the increased cost of the crystalline silicon panels may extend the payback period.

For this feasibility study, system calculations and sizes were based on site acreage; however, actual system installation should be based on the availability of funds or on the amount of power that can be sold. Installing a small demonstration system and adding capacity as funding becomes available might be a good option. When the system goes out to bid, a design-build contract should be issued that requests the best performance $(\mathrm{kWh} / \mathrm{yr})$ at the best price and which allows vendors to optimize system configuration, including slope. A third-party ownership PPA provides the most feasible way for a system to be financed on these sites. All payback calculations assumed that the $30 \%$ federal tax credit would be captured for the systems.

In the coming years, increasing electrical rates and increased necessity for clean power will continue to improve the feasibility of implementing solar PV systems at these sites. 


\section{Appendix A. Assumptions for Calculations*}

Table A-1. Assumptions for Calculations

\begin{tabular}{|c|c|c|c|c|c|c|c|c|}
\hline Location & $\begin{array}{l}\text { Array Tilt } \\
\text { (Deg) }\end{array}$ & $\begin{array}{l}\text { Max Usable } \\
\text { Area }\left(\mathrm{ft}^{\wedge} 2\right) \\
\end{array}$ & $\begin{array}{l}\text { Rounded PV } \\
\text { System Size (kW) }\end{array}$ & $\begin{array}{l}\text { Annual Output } \\
\text { (kWh/year) }\end{array}$ & $\begin{array}{l}\text { Annual Cost } \\
\text { Savings (\$/year) }\end{array}$ & $\begin{array}{l}\text { Annual O\&M } \\
\text { (\$lyear) }\end{array}$ & $\begin{array}{l}\text { System Cost with } \\
\text { Incentives (\$) }\end{array}$ & $\begin{array}{l}\text { Payback Period } \\
\text { (years) }\end{array}$ \\
\hline \multicolumn{9}{|l|}{ Crystalline Silicon (Fixed-Tilt) } \\
\hline Capped Landfill & 38.4 & 920,147 & 3,600 & $4,096,800$ & 327,744 & 30,600 & $12,600,000$ & 42 \\
\hline Temporarily Capped Landfill & 38.4 & 933,978 & 3,700 & $4,210,600$ & 336,848 & 31,450 & $12,950,000$ & 42 \\
\hline AC\&S Chemical & 38.4 & 87,120 & 350 & 398,300 & 31,864 & 2,975 & $1,225,000$ & 42 \\
\hline Partially Demolished Site & 38.4 & 503,771 & 2,000 & $2,276,000$ & 182,080 & 17,000 & $7,000,000$ & 42 \\
\hline Large Uncapped Field of Slabs & 38.4 & $2,803,086$ & 11,200 & $12,745,600$ & $1,019,648$ & 95,200 & $39,200,000$ & 42 \\
\hline Temporarily Capped Small Parcel & 38.4 & 117,612 & 450 & 512,100 & 40,968 & 3,825 & $1,575,000$ & 42 \\
\hline Temporarily Capped Small Landfill & 38.4 & 407,722 & 1,600 & $1,820,800$ & 145,664 & 13,600 & $5,600,000$ & 42 \\
\hline Partially Capped North Site & 38.4 & $1,183,961$ & 4,700 & $5,348,600$ & 427,888 & 39,950 & $16,450,000$ & 42 \\
\hline All Site Total & 38.4 & $6,957,397$ & 27,600 & $31,408,800$ & $2,512,700$ & 234,600 & $96,600,000$ & 42 \\
\hline \multicolumn{9}{|c|}{ Crystalline Silicon (Single-Axis Tracking) } \\
\hline Capped Landfill & 0 & 920,147 & 3,000 & $3,900,000$ & 312,000 & 63,000 & $12,600,000$ & 51 \\
\hline Temporarily Capped Landfill & 0 & 933,978 & 3,000 & $3,900,000$ & 312,000 & 63,000 & $12,600,000$ & 51 \\
\hline AC\&S Chemical & 0 & 87,120 & 250 & 325,000 & 26,000 & 5,250 & $1,050,000$ & 51 \\
\hline Partially Demolished Site & 0 & 503,771 & 1,600 & $2,080,000$ & 166,400 & 33,600 & $6,720,000$ & 51 \\
\hline Large Uncapped Field of Slabs & 0 & $2,803,086$ & 9,200 & $11,960,000$ & 956,800 & 193,200 & $38,640,000$ & 51 \\
\hline Temporarily Capped Small Parcel & 0 & 117,612 & 350 & 455,000 & 36,400 & 7,350 & $1,470,000$ & 51 \\
\hline Temporarily Capped Small Landfill & 0 & 407,722 & 1,300 & $1,690,000$ & 135,200 & 27,300 & $5,460,000$ & 51 \\
\hline Partially Capped North Site & 0 & $1,183,961$ & 3,900 & $5,070,000$ & 405,600 & 81,900 & $16,380,000$ & 51 \\
\hline All Site Total & 0 & $6,957,397$ & 22,600 & $29,380,000$ & $2,350,400$ & 474,600 & $94,920,000$ & 51 \\
\hline \multicolumn{9}{|l|}{ Thin Film ( Fixed-Tilt) } \\
\hline Capped Landfill & 38.4 & 920,147 & 1,500 & $1,707,000$ & 136,560 & 11,220 & $4,620,000$ & 37 \\
\hline Temporarily Capped Landfill & 38.4 & 933,978 & 1,500 & $1,707,000$ & 136,560 & 11,220 & $4,620,000$ & 37 \\
\hline AC\&S Chemical & 38.4 & 87,120 & 150 & 170,700 & 13,656 & 1,122 & 462,000 & 37 \\
\hline Partially Demolished Site & 38.4 & 503,771 & 850 & 967,300 & 77,384 & 6,358 & $2,618,000$ & 37 \\
\hline Large Uncapped Field of Slabs & 38.4 & $2,803,086$ & 4,700 & $5,348,600$ & 427,888 & 35,156 & $14,476,000$ & 37 \\
\hline Temporarily Capped Small Parcel & 38.4 & 117,612 & 200 & 227,600 & 18,208 & 1,496 & 616,000 & 37 \\
\hline Temporarily Capped Small Landfill & 38.4 & 407,722 & 650 & 739,700 & 59,176 & 4,862 & $2,002,000$ & 37 \\
\hline Partially Capped North Site & 38.4 & $1,183,961$ & 2,000 & $2,276,000$ & 182,080 & 14,960 & $6,160,000$ & 37 \\
\hline All Site Total & 38.4 & $6,957,397$ & 11,550 & $13,143,900$ & $1,051,510$ & 86,394 & $35,574,000$ & 37 \\
\hline
\end{tabular}

*These calculations assume that the $30 \%$ federal tax credit is secured 
Table A-2. Other Assumptions, including Assumptions for Costs and System Types

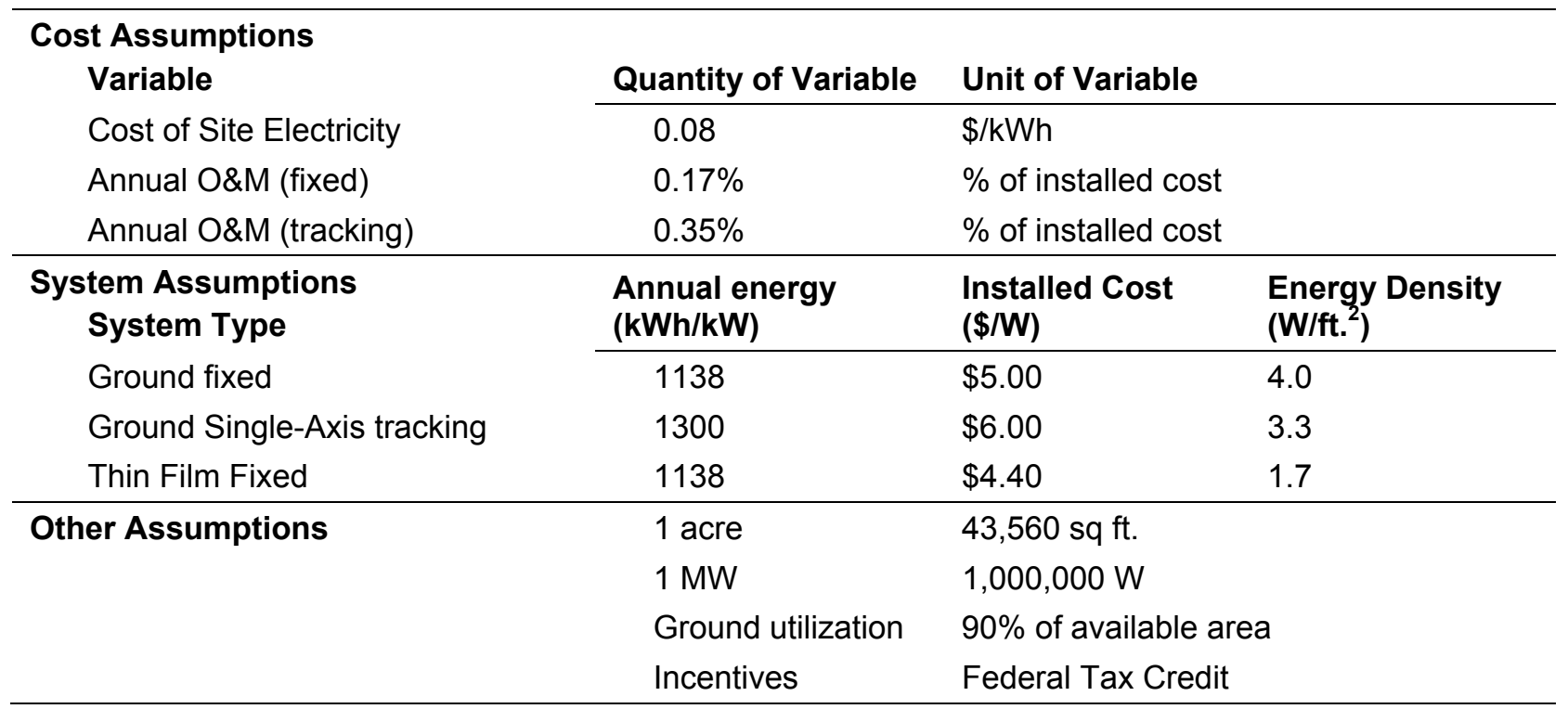




\section{Appendix B. Renewable Energy Incentives*}

Table B-1. Brownfield Redevelopment and Renewable Energy Incentives and Financing Tools

\begin{tabular}{|c|c|c|c|c|c|}
\hline Agency & Incentive Name & $\begin{array}{l}\text { Incentive (I), } \\
\text { Finance Tool } \\
\text { (FT) }\end{array}$ & Public & Private & Funding Range \\
\hline HUD & $\begin{array}{l}\text { Brownfield Economic Development Initiative } \\
\text { (BEDI) Competitive Grant Program }\end{array}$ & I & $x$ & $x^{b}$ & $\begin{array}{l}\text { \$17.5 million appropriated in FY10. } \\
\text { Award cap TBD as of } 2 / 27 / 10\end{array}$ \\
\hline HUD & Section 108 Loan Guarantee Program & $\mathrm{FT}$ & $\mathrm{X}$ & $X^{b}$ & $\begin{array}{l}\text { Up to } 5 \text { times public entity's latest } \\
\text { approved CDBG amount }\end{array}$ \\
\hline
\end{tabular}

${ }^{a}$ Must be used in conjunction with Section 108 loan guarantee commitment.

${ }^{\mathrm{b}}$ Through re-loan from public entity

Table B-2. Renewable Energy Development Incentives and Financing Tools Applicable to Photovoltaics

\begin{tabular}{|c|c|c|c|c|c|}
\hline Agency & Incentive Name & $\begin{array}{c}\text { Incentive (I), } \\
\text { Finance Tool } \\
\text { (FT) }\end{array}$ & Public & Private & Funding Range \\
\hline DOE & Loan Guarantee Program & FT & x & $\mathrm{X}$ & Not specified \\
\hline DOE & $\begin{array}{l}\text { Renewable Energy Production Incentive } \\
\text { (REPI) }\end{array}$ & 1 & $\mathrm{X}$ & & 2.1 cents per kilowatt \\
\hline HUD & $\begin{array}{l}\text { Community Development Block Grants } \\
\text { (CDBG) }\end{array}$ & 1 & $\mathrm{X}$ & & Based on community needs formula \\
\hline Treasury & $\begin{array}{l}1603 \text { Renewable Energy Grant Program } \\
\text { *option to ITC }\end{array}$ & 1 & & $\mathrm{x}$ & $\begin{array}{l}30 \% \text { of the cost basis of the } \\
\text { renewable energy project }\end{array}$ \\
\hline Treasury & $\begin{array}{l}\text { Business Energy Investment Tax Credit } \\
\text { (ITC) *option to } 1603\end{array}$ & 1 & & $\mathrm{x}$ & $30 \%$ of project expenditures \\
\hline Treasury & Clean Renewable Energy Bonds (CREB) & FT & $\mathrm{X}$ & & Varies \\
\hline Treasury & $\begin{array}{l}\text { Modified Accelerated Cost-Recovery } \\
\text { System (MACRS) }\end{array}$ & FT & & $x$ & Various depreciation deductions \\
\hline Treasury & $\begin{array}{l}\text { Qualified Energy Conservation Bonds } \\
\text { (QECB) }\end{array}$ & FT & $\mathrm{X}$ & & Varies \\
\hline USDA & $\begin{array}{l}\text { Rural Energy for America Program (REAP) } \\
\text { Grants }\end{array}$ & 1 & $\mathrm{X}$ & $x$ & $\begin{array}{l}25 \% \text { of project cost. Payment range } \\
\$ 2.5 \mathrm{~K}-\$ 500 \mathrm{~K}\end{array}$ \\
\hline USDA & $\begin{array}{l}\text { Rural Energy for America Program (REAP) } \\
\text { Loan Guarantees }\end{array}$ & $\mathrm{FT}$ & $X$ & $x$ & $\begin{array}{l}\text { Up to } 75 \% \text { of project costs. Max } \\
\$ 25 \mathrm{M} / \mathrm{Min} \$ 5 \mathrm{~K}\end{array}$ \\
\hline
\end{tabular}

* Sources: Database of State Incentives for Renewable Energy and Efficiency 2009; and U.S. Department of Housing and Urban Development 2009 


\section{Table B-3. State Rebates for Commercial-Sector PV Projects}

The programs included here are ongoing rebate and grant programs administered by state agencies or by third-party organizations on behalf of state governments. In addition to the programs highlighted above, about 75 utilities in the United States offer PV rebates. In some states, such as Colorado and Arizona, solar rebates are available nearly statewide from utilities that must comply with state renewable portfolio standards, but these are not shown in the table. Finally, programs that are purely performance-based, such as the state of Washington's production incentive and California's feed-in tariff, are not included in this table.

\begin{tabular}{|c|c|c|c|c|}
\hline State & Program Name & Incentive Amount & REC Ownership & Funding Source \\
\hline California & California Solar Initiative & Varies by sector and system size & $\begin{array}{l}\text { Remains with project } \\
\text { owner }\end{array}$ & Rate-payer funds \\
\hline California & $\begin{array}{l}\text { CEC - New Solar Homes } \\
\text { Partnership }\end{array}$ & $\begin{array}{l}\text { Varies. Incentives are adjusted } \\
\text { based on expected performance, } \\
\text { and will decline over time based on } \\
\text { the total installed capacity. }\end{array}$ & $\begin{array}{l}\text { Remains with system } \\
\text { owner }\end{array}$ & Rate payer funded \\
\hline Connecticut & $\begin{array}{l}\text { CCEF - On-Site } \\
\text { Renewable DG Program }\end{array}$ & $\begin{array}{l}\text { For for-profit owners: } \$ 3.00 / \mathrm{W} \text { for } \\
\text { first } 100 \mathrm{~kW}, \$ 2.00 / \mathrm{W} \text { for next } 100 \\
\mathrm{~kW} \text {. Not-for-profit system owners: } \\
\$ 4.50 / \mathrm{W} \text { for first } 100 \mathrm{~kW}, \$ 4.00 / \mathrm{W} \text { for } \\
\text { next } 100 \mathrm{~kW} \text {. Additional } \$ 0.10 / \mathrm{W} \\
\text { premium for buildings that meet } \\
\text { LEED Silver certification; CCEF also } \\
\text { compensates system owners based } \\
\text { on the estimated present value of the } \\
\text { system's RECs. }\end{array}$ & $\begin{array}{l}\text { RECs transfer to CCEF } \\
\text { for systems } 50 \mathrm{~kW}-\mathrm{PTC} \\
\text { and larger. CCEF } \\
\text { compensates system } \\
\text { owners based on } \\
\text { estimated present value } \\
\text { of the system's RECs } \\
\text { over } 15 \text { yrs. }\end{array}$ & $\begin{array}{l}\text { Connecticut Clean Energy Fund } \\
\text { (public benefits fund) }\end{array}$ \\
\hline Delaware & $\begin{array}{l}\text { Green Energy Program } \\
\text { Incentives }\end{array}$ & $\begin{array}{l}\text { Delmarva: } 25 \% \text { of installed cost } \\
\text { (35\% for non-profits, government); } \\
\text { DEC: } 33.3 \% \text { of installed cost; Minis: } \\
33.3 \% \text { of installed cost, except } 25 \% \\
\text { for Dover, Seaford; PV system cost } \\
\text { may not exceed } \$ 12 / \mathrm{W}\end{array}$ & $\begin{array}{l}\text { Remains with project } \\
\text { owner }\end{array}$ & $\begin{array}{l}\text { Green Energy Fund (Delmarva), } \\
\text { DEC Renewable Resources } \\
\text { Fund, Municipal Utility Green } \\
\text { Energy Fund (public benefits } \\
\text { funds) }\end{array}$ \\
\hline $\begin{array}{l}\text { District of } \\
\text { Columbia }\end{array}$ & $\begin{array}{l}\text { Renewable Energy } \\
\text { Incentive Program }\end{array}$ & $\begin{array}{l}\text { \$3/W DC for first } 3 \mathrm{~kW} ; \text { \$2/W DC for } \\
\text { next } 7 \mathrm{~kW} ; \$ 1 / \mathrm{W} \text { DC for next } 10 \mathrm{~kW}\end{array}$ & $\begin{array}{l}\text { Remains with system } \\
\text { owner }\end{array}$ & $\begin{array}{l}\text { Sustainable Energy Trust Fund } \\
\text { (public benefits fund) }\end{array}$ \\
\hline Florida & $\begin{array}{l}\text { Solar Energy System } \\
\text { Incentives Program }\end{array}$ & \$4/watt DC & $\begin{array}{l}\text { Remains with system } \\
\text { owner }\end{array}$ & $\begin{array}{l}\text { General Revenue Funds } \\
\text { (appropriated annually) }\end{array}$ \\
\hline Illinois & $\begin{array}{l}\text { DCEO - Solar and Wind } \\
\text { Energy Rebate Program }\end{array}$ & $\begin{array}{l}\text { NOTE (02/2010): Funding for FY } \\
2010 \text { has been fully allocated; no }\end{array}$ & $\begin{array}{l}\text { Remains with } \\
\text { customer/producer }\end{array}$ & $\begin{array}{l}\text { Illinois Renewable Energy } \\
\text { Resources Trust Fund (public }\end{array}$ \\
\hline
\end{tabular}




\begin{tabular}{|c|c|c|c|c|}
\hline State & Program Name & Incentive Amount & REC Ownership & Funding Source \\
\hline & & $\begin{array}{l}\text { additional rebates are available. } \\
\text { Residential and commercial: } 30 \% \text {; } \\
\text { Non-profit and Public: } 50 \%\end{array}$ & & benefits fund) \\
\hline Maine & $\begin{array}{l}\text { Solar and Wind Energy } \\
\text { Rebate Program }\end{array}$ & $\$ 2 / \mathrm{W} A C$ & $\begin{array}{l}\text { Remains with } \\
\text { customer/producer }\end{array}$ & $\begin{array}{l}\text { Funded by assessment of up to } \\
0.005 \text { cents/kWh on transmission } \\
\text { and distribution utilities; Plus } \\
\$ 500,000 \text { per fiscal year (FY2009- } \\
10 \text { and FY2010-11) for two years } \\
\text { using American Recovery and } \\
\text { Reinvestment Act of } 2009 \\
\text { (Recovery Act) funding. }\end{array}$ \\
\hline Maryland & $\begin{array}{l}\text { Mid-Size Solar Energy } \\
\text { Grant Program }\end{array}$ & $\begin{array}{l}\$ 500 / \mathrm{kW} \text { for first } 20 \mathrm{~kW} \mathrm{DC} ; \\
\$ 250 / \mathrm{kW} \text { for next } 30 \mathrm{~kW} ; \$ 150 / \mathrm{kW} \\
\text { for next } 50 \mathrm{~kW}\end{array}$ & $\begin{array}{l}\text { Remains with project } \\
\text { owner }\end{array}$ & Recovery Act \\
\hline Maryland & $\begin{array}{l}\text { Solar Energy Grant } \\
\text { Program }\end{array}$ & $\begin{array}{l}\$ 1.25 / \mathrm{W} D C \text { for first } 2 \mathrm{~kW} ; \$ 0.75 / \mathrm{W} \\
\text { for next } 6 \mathrm{~kW} ; \$ 0.25 / \mathrm{W} \text { for next } 12 \\
\mathrm{~kW}\end{array}$ & $\begin{array}{l}\text { Remains with project } \\
\text { owner }\end{array}$ & $\begin{array}{l}\text { General Revenue Funds } \\
\text { (appropriated annually); FY } 2009 \\
\text { funds supplemented with RGGI } \\
\text { proceeds }\end{array}$ \\
\hline Massachusetts & $\begin{array}{l}\text { CEC - Commonwealth } \\
\text { Solar II Rebates }\end{array}$ & $\begin{array}{l}\$ 1 / \mathrm{W} \text { DC base; } \$ 0.10 / \mathrm{W} \text { DC adder } \\
\text { for MA components; } \$ 1.00 / \mathrm{W} \text { DC } \\
\text { adder for moderate home value or } \\
\text { for moderate income }\end{array}$ & $\begin{array}{l}\text { Remains with project } \\
\text { owner }\end{array}$ & $\begin{array}{l}\text { Massachusetts Renewable } \\
\text { Energy Trust }\end{array}$ \\
\hline Massachusetts & $\begin{array}{l}\text { CEC - Commonwealth } \\
\text { Solar Stimulus }\end{array}$ & $\begin{array}{l}\$ 1.50 / \mathrm{W}(\mathrm{DC}) \text { for first } 25 \mathrm{~kW} ; \\
\$ 1.00 / \mathrm{W}(\mathrm{DC}) \text { for }>25 \mathrm{~kW} \text { to } 100 \mathrm{w} \\
\mathrm{kW} ; \$ 0.50 / \mathrm{W} \text { (DC) for }>100 \mathrm{~kW} \text { to } \\
200 \mathrm{~kW}\end{array}$ & $\begin{array}{l}\text { Remains with project } \\
\text { owner }\end{array}$ & $\begin{array}{l}\text { The American Recovery and } \\
\text { Reinvestment Act (ARRA) }\end{array}$ \\
\hline Nevada & $\begin{array}{l}\text { NV Energy - Renewable } \\
\text { Generations Rebate } \\
\text { Program }\end{array}$ & $\begin{array}{l}\text { (2010-2011 program year) } \\
\text { Residential and small business: } \\
\text { \$2.30/W AC; Public } \\
\text { Facilities/Schools: } \$ 5.00 / W \text { AC }\end{array}$ & NV Energy & Rate-payer funded \\
\hline New Jersey & $\begin{array}{l}\text { New Jersey Customer- } \\
\text { Sited Renewable Energy } \\
\text { Rebates }\end{array}$ & $\begin{array}{l}\text { Standard residential: } \$ 1.55 / \mathrm{W} \text { DC; } \\
\text { Residential w/energy efficiency: } \\
\$ 1.75 / \mathrm{W} \text { DC; Residential New } \\
\text { Construction: varies by efficiency, } \\
\$ 1.00 \text { - 1.75/W DC; Standard non- } \\
\text { residential: \$0.90/W DC; Non- }\end{array}$ & $\begin{array}{l}\text { Remains with project } \\
\text { owner }\end{array}$ & $\begin{array}{l}\text { New Jersey Societal Benefits } \\
\text { Charge (public benefits fund) }\end{array}$ \\
\hline
\end{tabular}




\begin{tabular}{|c|c|c|c|c|}
\hline State & Program Name & Incentive Amount & REC Ownership & Funding Source \\
\hline & & residential w/efficiency: \$1.00/W DC & & \\
\hline New Jersey & $\begin{array}{l}\text { Renewable Energy } \\
\text { Manufacturing Incentives } \\
\text { (for End-Use PV } \\
\text { Installations) }\end{array}$ & $\begin{array}{l}\text { Varies by equipment type, sector, } \\
\text { and system size; Ranges from } \$ 0.05 \\
\text { - } \$ 0.55 / \mathrm{W} \text { DC. }\end{array}$ & Not applicable & $\begin{array}{l}\text { New Jersey Societal Benefits } \\
\text { Charge (public benefits fund) }\end{array}$ \\
\hline New York & $\begin{array}{l}\text { NYSERDA - PV Incentive } \\
\text { Program }\end{array}$ & $\begin{array}{l}\text { Residential (first } 5 \mathrm{~kW}) \text { : } \$ 1.75 / \mathrm{W} \text { DC; } \\
\text { Non-Residential (first } 50 \mathrm{~kW}) \text { : } \\
\text { \$1.75/W DC; Non-profit, } \\
\text { government, schools: (first } 25 \mathrm{~kW} \text { ): } \\
\text { \$1.75/W DC; Bonus incentive: } \\
\text { \$0.50/W for Energy Star Homes and } \\
\text { BIPV systems }\end{array}$ & $\begin{array}{l}\text { First } 3 \text { years: } \\
\text { NYSERDA, thereafter } \\
\text { customer/generator }\end{array}$ & RPS surcharge \\
\hline Ohio & $\begin{array}{l}\text { ODOD - Advanced } \\
\text { Energy Program Grants - } \\
\text { Non-Residential } \\
\text { Renewable Energy } \\
\text { Incentive }\end{array}$ & $\begin{array}{l}\$ 3.50 \text { per DC watt, may be reduced } \\
\text { by shading }\end{array}$ & Not specified & Ohio Advanced Energy Fund \\
\hline Oregon & $\begin{array}{l}\text { Energy Trust - Solar } \\
\text { Electric Buy-Down } \\
\text { Program }\end{array}$ & $\begin{array}{l}\text { Residential: \$1.50/W DC for Pacific } \\
\text { Power; } \$ 1.75 / \mathrm{W} \text { DC for PGE; } \\
\text { Residential, Third Party: \$1/W DC for } \\
\text { Pacific Power; } \$ 1.25 / \mathrm{W} \text { DC for PGE; } \\
\text { Commercial: } \$ 1 / \mathrm{W} \text { - \$0.50/W for } \\
\text { Pacific Power; } \$ 1.25 / \mathrm{W} \text { - } \$ 0.75 / \mathrm{W} \text { for } \\
\text { PGE; nonprofit/government: } \$ 1.25 / \mathrm{W} \\
\text { - \$0.75/W for Pacific Power; } \$ 1.50 / \mathrm{W} \\
\text { - \$1/W for PGE }\end{array}$ & $\begin{array}{l}\text { Residential: RECs for } \\
\text { first } 5 \text { yrs. owned by } \\
\text { customer/producer; } \\
\text { Non-residential: RECs } \\
\text { for first } 5 \text { yrs. owned by } \\
\text { consumer/producer, } \\
\text { Energy Trust owns } \\
\text { RECs for years } 6-20\end{array}$ & $\begin{array}{l}\text { Energy Trust of Oregon (public } \\
\text { benefits fund) }\end{array}$ \\
\hline Pennsylvania & $\begin{array}{l}\text { Pennsylvania Sunshine } \\
\text { Solar Rebate Program }\end{array}$ & $\begin{array}{l}\text { Residential: } \$ 2.25 / \mathrm{W} \text { DC; } \\
\text { Commercial: } \$ 1.25 / \mathrm{W} \text { DC for first } 10 \\
\text { kW, } \$ 1.00 / \mathrm{W} \text { DC for next } 90 \mathrm{~kW}, \\
\$ 0.75 / \mathrm{W} \text { DC for next } 100 \mathrm{~kW} ; \text { Low- } \\
\text { Income: } 35 \% \text { of installed costs }\end{array}$ & $\begin{array}{l}\text { Not specified, but net } \\
\text { metering customers } \\
\text { generally retain title to } \\
\text { RECs }\end{array}$ & $\begin{array}{l}\text { Pennsylvania Energy } \\
\text { Independence Fund (state bonds) }\end{array}$ \\
\hline Puerto Rico & $\begin{array}{l}\text { Puerto Rico - State } \\
\text { Energy Program - Sun } \\
\text { Energy Rebate Program }\end{array}$ & $\begin{array}{l}\text { Solar PV: Residential and } \\
\text { Commercial } \$ 4 / \text { watt (DC) Solar PV: } \\
\text { Governmental } \$ 8 / \text { watt (DC) }\end{array}$ & Not addressed & $\begin{array}{l}\text { The American Recovery and } \\
\text { Reinvestment Act State Energy } \\
\text { Program funds }\end{array}$ \\
\hline Tennessee & $\begin{array}{l}\text { Tennessee Clean Energy } \\
\text { Technology Grant }\end{array}$ & $40 \%$ of installed cost & Not specified & $\begin{array}{l}\text { State of Tennessee Economic } \\
\text { and Community Development }\end{array}$ \\
\hline
\end{tabular}




\begin{tabular}{|c|c|c|c|c|}
\hline \multirow[t]{2}{*}{ State } & Program Name & Incentive Amount & REC Ownership & Funding Source \\
\hline & & & & Energy Division \\
\hline Vermont & $\begin{array}{l}\text { Vermont Small-Scale } \\
\text { Renewable Energy } \\
\text { Incentive Program }\end{array}$ & $\begin{array}{l}\text { Individuals/Businesses: } \$ 1.75 / \text { watt } \\
\text { DC; Multi-family, low-income: } \\
\$ 3.50 / \text { W DC }\end{array}$ & Not addressed & $\begin{array}{l}\text { Utility settlement funds and the } \\
\text { Vermont Clean Energy } \\
\text { Development Fund }\end{array}$ \\
\hline Wisconsin & $\begin{array}{l}\text { Focus on Energy - } \\
\text { Renewable Energy Cash- } \\
\text { Back Rewards }\end{array}$ & $\begin{array}{l}\text { Residential/Business: } \$ 1.00 / \mathrm{kWh} / 1 \text { - } \\
\text { yr.; non-profit/government: } \\
\$ 1.50 / \mathrm{kWh} / 1-y r . ; ~(E s t i m a t e d ~ 1-y r . \\
\text { production using PV Watts). } \\
\text { Efficiency First participants: add } \\
\$ 0.25 / \mathrm{kWh} / 1 \text {-yr. }\end{array}$ & Not addressed & Focus on Energy Program \\
\hline
\end{tabular}

Source: Database of State Incentives for Renewable Energy and Efficiency 2010

Please note: The information provided in this table presents an overview of state incentives, but it should not be used as the only source of

information when making purchasing decisions, investment decisions, tax decisions or other binding agreements. For more information about individual programs listed above, visit the DSIRE Web site at http://www.dsireusa.org/. 
Table B-4. State Tax Credits for Commercial-Sector PV Projects

\begin{tabular}{|c|c|c|c|c|c|}
\hline State & Program Name & Eligible Recipients & $\begin{array}{c}\text { Incentive } \\
\text { Amount }\end{array}$ & $\begin{array}{c}\text { Third-Party Owner } \\
\text { Eligible }\end{array}$ & $\begin{array}{c}\text { Non-Profit/Government } \\
\text { Eligible }\end{array}$ \\
\hline Arizona & $\begin{array}{l}\text { Non-Residential } \\
\text { Solar \& Wind } \\
\text { Tax Credit } \\
\text { (Corporate) }\end{array}$ & $\begin{array}{l}\text { Any non-residential installation is } \\
\text { eligible, including those for non- } \\
\text { profits and governments. } \\
\text { Individuals, corporations and S } \\
\text { corporations and partnerships may } \\
\text { claim the credit. Third party } \\
\text { financiers/installers/mfrs. of eligible } \\
\text { system may claim the credit. }\end{array}$ & $10 \%$ & Yes & Yes \\
\hline Florida & $\begin{array}{l}\text { Renewable } \\
\text { Energy } \\
\text { Production Tax } \\
\text { Credit }\end{array}$ & $\begin{array}{l}\text { A non-residential taxpayer with } \\
\text { facility placed in service or } \\
\text { expanded after May } 1,2006 \text {. The } \\
\text { credit is for electricity produced and } \\
\text { sold by the taxpayer to an unrelated } \\
\text { party during a given tax year. } \\
\text { Florida corporate income taxpayers } \\
\text { who own an interest in a general } \\
\text { partnership, limited partnership, } \\
\text { limited liability company, trust or } \\
\text { other artificial entity that owns a } \\
\text { Florida renewable energy facility } \\
\text { can apply for this credit. }\end{array}$ & $\$ 0.01 / \mathrm{kWh}$ & Not specified & Not specified \\
\hline Georgia & $\begin{array}{l}\text { Clean Energy } \\
\text { Tax Credit } \\
\text { (Corporate) }\end{array}$ & $\begin{array}{l}\text { Any GA taxpayer who has } \\
\text { constructed, purchased, or leased } \\
\text { renewable energy property and } \\
\text { placed it in service. }\end{array}$ & $35 \%$ & Yes & Not specified \\
\hline Hawaii & $\begin{array}{l}\text { Solar and Wind } \\
\text { Energy Credit } \\
\text { (Corporate) }\end{array}$ & $\begin{array}{l}\text { Hawaii taxpayer that files a } \\
\text { corporate net income tax return or } \\
\text { franchise tax return; Credit may be } \\
\text { claimed for every eligible renewable } \\
\text { energy technology system that is } \\
\text { installed and placed in service. } \\
\text { Third-party taxpaying entities may } \\
\text { claim the credit if they install and } \\
\text { own a system on a commercial } \\
\text { taxpayer's building or on a non-profit }\end{array}$ & $35 \%$ & Yes & Yes \\
\hline
\end{tabular}




\begin{tabular}{|c|c|c|c|c|c|}
\hline State & Program Name & Eligible Recipients & $\begin{array}{c}\text { Incentive } \\
\text { Amount }\end{array}$ & $\begin{array}{c}\text { Third-Party Owner } \\
\text { Eligible }\end{array}$ & $\begin{array}{c}\text { Non-Profit/Government } \\
\text { Eligible }\end{array}$ \\
\hline & & $\begin{array}{l}\text { or government building. Multiple } \\
\text { owners of a single system may take } \\
\text { a single tax credit. The credit is } \\
\text { apportioned between the owners in } \\
\text { proportion to their contribution to the } \\
\text { system's cost. }\end{array}$ & & & \\
\hline lowa & $\begin{array}{l}\text { Renewable } \\
\text { Energy } \\
\text { Production Tax } \\
\text { Credits } \\
\text { (Corporate) }\end{array}$ & $\begin{array}{l}\text { Producers or purchasers of } \\
\text { renewable energy from qualified } \\
\text { facilities; Installations must be at } \\
\text { least } 51 \% \text { owned by a state resident } \\
\text { or other qualifying owner, and } \\
\text { placed in service on or after July } 1 \text {, } \\
2005 \text { and before January } 1,2012 \text {. } \\
\text { Electricity must be sold to an } \\
\text { unrelated person to qualify for the } \\
\text { tax credit. }\end{array}$ & $\begin{array}{l}\$ 0.015 / \mathrm{kWh} \text { for } \\
10 \text { years after } \\
\text { energy } \\
\text { production } \\
\text { begins. }\end{array}$ & $\begin{array}{l}\text { Yes, credits may be } \\
\text { claimed by system owner } \\
\text { or by purchaser of } \\
\text { electricity. System owners } \\
\text { must meet certain eligibility } \\
\text { criteria. }\end{array}$ & $\begin{array}{l}\text { Schools and cooperative } \\
\text { associations are eligible } \\
\text { owners. Credits may be } \\
\text { transferred or sold one } \\
\text { time. }\end{array}$ \\
\hline Kentucky & $\begin{array}{l}\text { Renewable } \\
\text { Energy Tax } \\
\text { Credit } \\
\text { (Corporate) }\end{array}$ & $\begin{array}{l}\text { Any installation on a dwelling unit or } \\
\text { on property that is owned and used } \\
\text { by the taxpayer as commercial } \\
\text { property }\end{array}$ & $\$ 3.00 /$ watt (DC) & Not specified & Not specified \\
\hline Kentucky & $\begin{array}{l}\text { Tax Credit for } \\
\text { Renewable } \\
\text { Energy } \\
\text { Facilities }\end{array}$ & $\begin{array}{l}\text { Companies that build or renovate } \\
\text { facilities that utilize renewable } \\
\text { energy }\end{array}$ & $\begin{array}{l}100 \% \text { Kentucky } \\
\text { income tax or } \\
\text { limited liability } \\
\text { entity tax }\end{array}$ & Not specified & Not specified \\
\hline Louisiana & $\begin{array}{l}\text { Tax Credit for } \\
\text { Solar and Wind } \\
\text { Energy } \\
\text { Systems on } \\
\text { Residential } \\
\text { Property } \\
\text { (Corporate) }\end{array}$ & $\begin{array}{l}\text { A taxpayer who purchases and } \\
\text { installs an eligible system or who } \\
\text { purchases a new home with such a } \\
\text { system already in place }\end{array}$ & $50 \%$ & No & No \\
\hline Maryland & $\begin{array}{l}\text { Clean Energy } \\
\text { Production Tax } \\
\text { Credit } \\
\text { (Corporate) }\end{array}$ & $\begin{array}{l}\text { All individuals and corporations that } \\
\text { sell electricity produced by a } \\
\text { qualified facility to an unrelated } \\
\text { person; Net metering arrangements } \\
\text { qualify. }\end{array}$ & $\begin{array}{l}\$ 0.0085 / \mathrm{kWh} \\
\text { for } 5 \text { years after } \\
\text { facility is placed } \\
\text { in service. }\end{array}$ & Not specified & No \\
\hline
\end{tabular}




\begin{tabular}{|c|c|c|c|c|c|}
\hline State & Program Name & Eligible Recipients & $\begin{array}{l}\text { Incentive } \\
\text { Amount }\end{array}$ & $\begin{array}{c}\text { Third-Party Owner } \\
\text { Eligible }\end{array}$ & $\begin{array}{c}\text { Non-Profit/Government } \\
\text { Eligible }\end{array}$ \\
\hline Montana & $\begin{array}{l}\text { Alternative } \\
\text { Energy } \\
\text { Investment Tax } \\
\text { Credit } \\
\text { (Corporate) }\end{array}$ & $\begin{array}{l}\text { A corporation, partnership, or small } \\
\text { business corporation that makes a } \\
\text { minimum investment of } \$ 5,000\end{array}$ & $35 \%$ & No & No \\
\hline $\begin{array}{l}\text { New } \\
\text { Mexico }\end{array}$ & $\begin{array}{l}\text { Advanced } \\
\text { Energy Tax } \\
\text { Credit } \\
\text { (Corporate) }\end{array}$ & Any taxpayer & $6 \%$ & No. & No. \\
\hline $\begin{array}{l}\text { New } \\
\text { Mexico }\end{array}$ & $\begin{array}{l}\text { Renewable } \\
\text { Energy } \\
\text { Production Tax } \\
\text { Credit } \\
\text { (Corporate) }\end{array}$ & $\begin{array}{l}\text { A taxpayer who holds title to a } \\
\text { qualified energy generator that first } \\
\text { produced electricity on or before } \\
\text { January } 1,2018 ; \text { or a taxpayer who } \\
\text { leases property upon which a } \\
\text { qualified energy generator operates } \\
\text { from a county or municipality under } \\
\text { authority of an industrial revenue } \\
\text { bond and if the qualified energy } \\
\text { generator first produced electricity } \\
\text { on or before January } 1,2018 \text {. }\end{array}$ & $\begin{array}{l}\text { Varies annually } \\
\text { over } 10 \text { years; } \\
\$ 0.027 / \mathrm{kWh} \\
\text { average }\end{array}$ & Not specified & Not specified \\
\hline $\begin{array}{l}\text { New } \\
\text { Mexico }\end{array}$ & $\begin{array}{l}\text { Solar Market } \\
\text { Development } \\
\text { Tax Credit }\end{array}$ & $\begin{array}{l}\text { Residents and non-corporate } \\
\text { businesses, including agricultural } \\
\text { enterprises }\end{array}$ & $\begin{array}{l}10 \% \text { of } \\
\text { purchase and } \\
\text { installation } \\
\text { costs }\end{array}$ & No & No \\
\hline $\begin{array}{l}\text { North } \\
\text { Carolina }\end{array}$ & $\begin{array}{l}\text { Renewable } \\
\text { Energy Tax } \\
\text { Credit } \\
\text { (Corporate) }\end{array}$ & $\begin{array}{l}\text { Any NC taxpayer who has } \\
\text { constructed, purchased, or leased } \\
\text { renewable energy property and } \\
\text { placed it in service. }\end{array}$ & $\begin{array}{l}35 \% \\
\text { (distributed } 7 \% \\
\text { per year for } 5 \\
\text { years for non- } \\
\text { residential } \\
\text { installations) }\end{array}$ & $\begin{array}{l}\text { Yes. For leasing, a } \\
\text { taxpayer may take credit } \\
\text { for property that the } \\
\text { taxpayer leases if written } \\
\text { verification is received } \\
\text { from the owner that states } \\
\text { that owner will not take } \\
\text { credit for renewable } \\
\text { energy installation. }\end{array}$ & No \\
\hline $\begin{array}{l}\text { North } \\
\text { Dakota }\end{array}$ & $\begin{array}{l}\text { Renewable } \\
\text { Energy Tax } \\
\text { Credit }\end{array}$ & $\begin{array}{l}\text { Corporate taxpayers filing a North } \\
\text { Dakota income tax return. System } \\
\text { must be installed on a building or on }\end{array}$ & $\begin{array}{l}15 \% \\
\text { (distributed } 3 \% \\
\text { per year for } 5\end{array}$ & $\begin{array}{l}\text { A pass-through entity that } \\
\text { installs the system at a } \\
\text { property it owns or leases }\end{array}$ & No \\
\hline
\end{tabular}




\begin{tabular}{|c|c|c|c|c|c|}
\hline \multirow[t]{2}{*}{ State } & Program Name & Eligible Recipients & $\begin{array}{l}\text { Incentive } \\
\text { Amount }\end{array}$ & $\begin{array}{c}\text { Third-Party Owner } \\
\text { Eligible }\end{array}$ & $\begin{array}{c}\text { Non-Profit/Government } \\
\text { Eligible }\end{array}$ \\
\hline & & $\begin{array}{l}\text { property owned or leased by the } \\
\text { taxpayer in North Dakota. }\end{array}$ & years) & $\begin{array}{l}\text { is considered the taxpayer. } \\
\text { The credit amount allowed } \\
\text { is determined at the pass- } \\
\text { through entity level and } \\
\text { must be passed through } \\
\text { proportionally to corporate } \\
\text { partners, shareholders or } \\
\text { members. }\end{array}$ & \\
\hline Oklahoma & $\begin{array}{l}\text { Zero-Emission } \\
\text { Facilities } \\
\text { Production Tax } \\
\text { Credit }\end{array}$ & $\begin{array}{l}\text { Any non-residential taxpayer who } \\
\text { sells electricity to an unrelated } \\
\text { person; Any nontaxable entities, } \\
\text { including agencies of the State of } \\
\text { Oklahoma, may transfer their credit } \\
\text { to a taxpayer. }\end{array}$ & $\begin{array}{l}\$ 0.0050 / \mathrm{kWh} \\
\text { for first } 10 \text { years } \\
\text { of operation }\end{array}$ & Yes & $\begin{array}{l}\text { Yes, nontaxable entities, } \\
\text { including agencies of the } \\
\text { State of Oklahoma or } \\
\text { political subdivisions } \\
\text { thereof, can take } \\
\text { advantage of the tax credit } \\
\text { by transferring it to a } \\
\text { taxable entity. }\end{array}$ \\
\hline Oregon & $\begin{array}{l}\text { Business } \\
\text { Energy Tax } \\
\text { Credit }\end{array}$ & $\begin{array}{l}\text { Trade, business or rental property } \\
\text { owners who pay taxes for a } \\
\text { business site in Oregon are eligible } \\
\text { for the tax credit. The business, its } \\
\text { partners or its shareholders may } \\
\text { use the credit. A project owner also } \\
\text { can be an Oregon non-profit } \\
\text { organization, tribe or public entity } \\
\text { that partners with an Oregon } \\
\text { business or resident who has an } \\
\text { Oregon tax liability. This can be } \\
\text { done using the pass-through option. }\end{array}$ & $\begin{array}{l}50 \% \\
\text { (distributed } \\
10 \% \text { per year } \\
\text { for } 5 \text { years) }\end{array}$ & Yes & $\begin{array}{l}\text { A project owner can be a } \\
\text { non-profit, tribe or public } \\
\text { entity that partners with a } \\
\text { business or resident to } \\
\text { take advantage of the } \\
\text { pass-through option. The } \\
\text { pass-through option allows } \\
\text { a project owner to transfer } \\
\text { the } 35 \text { percent Business } \\
\text { Energy Tax Credit project } \\
\text { eligibility to a pass-through } \\
\text { partner for a lump-sum } \\
\text { cash payment. The pass- } \\
\text { through option rate for five- } \\
\text { year Business Energy Tax } \\
\text { Credits effective October } \\
1,2003 \text { is } 25.5 \text { percent. } \\
\text { The pass-through option } \\
\text { rate for one-year Business } \\
\text { Energy Tax Credits (those } \\
\text { with eligible costs of }\end{array}$ \\
\hline
\end{tabular}




\begin{tabular}{|c|c|c|c|c|c|}
\hline State & Program Name & Eligible Recipients & $\begin{array}{l}\text { Incentive } \\
\text { Amount }\end{array}$ & $\begin{array}{l}\text { Third-Party Owner } \\
\text { Eligible }\end{array}$ & $\begin{array}{c}\text { Non-Profit/Government } \\
\text { Eligible }\end{array}$ \\
\hline & & & & & $\begin{array}{l}\$ 20,000 \text { or less) effective } \\
\text { October } 1,2003 \text { is } 30.5 \\
\text { percent. }\end{array}$ \\
\hline $\begin{array}{l}\text { Puerto } \\
\text { Rico }\end{array}$ & $\begin{array}{l}\text { Puerto Rico - } \\
\text { Solar Tax } \\
\text { Credit } \\
\text { (Corporate) }\end{array}$ & $\begin{array}{l}\text { Any Puerto Rican taxpayer who has } \\
\text { acquired, assembled, and installed } \\
\text { eligible solar electric equipment. }\end{array}$ & $\begin{array}{l}75 \% \text { during } F Y \\
2007-08 \text { and } \\
2008-09 ; 50 \% \\
\text { during FY 2009- } \\
10 \text { and FY } \\
2010-11 ; 25 \% \\
\text { starting FY } \\
2011-12\end{array}$ & Not specified & $\begin{array}{l}\text { Potentially; the tax credit } \\
\text { may be transferred, sold or } \\
\text { otherwise given to "any } \\
\text { other person." }\end{array}$ \\
\hline $\begin{array}{l}\text { Rhode } \\
\text { Island }\end{array}$ & $\begin{array}{l}\text { Residential } \\
\text { Renewable } \\
\text { Energy Tax } \\
\text { Credit } \\
\text { (Corporate) }\end{array}$ & $\begin{array}{l}\text { Rhode Island taxpayer who (1) } \\
\text { owns, rents, or is the contract buyer } \\
\text { of the dwelling(s) served by the } \\
\text { system; The dwelling or dwellings } \\
\text { must be in the main or secondary } \\
\text { residence of the person who applies } \\
\text { for the tax credit, or of a tenant; or } \\
\text { (2) owns, or is the contract buyer of } \\
\text { the system and pays all or part of } \\
\text { the cost of the system; or (3) is the } \\
\text { contractor that owns the dwelling for } \\
\text { speculative sale in which the system } \\
\text { is installed }\end{array}$ & $25 \%$ & $\begin{array}{l}\text { Yes. Credit is available to } \\
\mathrm{RI} \text { taxpayers who are the } \\
\text { contract buyers of eligible } \\
\text { systems and pay all or part } \\
\text { of the cost of the system. }\end{array}$ & No \\
\hline $\begin{array}{l}\text { South } \\
\text { Carolina }\end{array}$ & $\begin{array}{l}\text { Solar Energy } \\
\text { and Small } \\
\text { Hydropower } \\
\text { Tax Credit } \\
\text { (Corporate) }\end{array}$ & $\begin{array}{l}\text { Taxpayers who purchase and install } \\
\text { an eligible system in or on a facility } \\
\text { owned by the taxpayer }\end{array}$ & $\begin{array}{l}25 \% \text { for } 2010 \\
\text { was } 30 \% \text { in } \\
2009\end{array}$ & No & No \\
\hline Utah & $\begin{array}{l}\text { Renewable } \\
\text { Energy } \\
\text { Systems Tax } \\
\text { Credit } \\
\text { (Corporate) }\end{array}$ & $\begin{array}{l}\text { Any company that owns a qualified } \\
\text { system }\end{array}$ & $\begin{array}{l}\text { Residential: } \\
25 \% \text {; } \\
\text { Commercial: } \\
10 \%\end{array}$ & No & No \\
\hline Vermont & $\begin{array}{l}\text { Business Tax } \\
\text { Credit for Solar }\end{array}$ & $\begin{array}{l}\text { Corporations that pay corporate } \\
\text { income tax in Vermont that do not }\end{array}$ & $\begin{array}{l}30 \% \text { of } \\
\text { expenditures }\end{array}$ & Not specified & No \\
\hline
\end{tabular}




\begin{tabular}{|c|c|c|c|c|c|}
\hline State & Program Name & Eligible Recipients & $\begin{array}{c}\text { Incentive } \\
\text { Amount }\end{array}$ & $\begin{array}{c}\text { Third-Party Owner } \\
\text { Eligible }\end{array}$ & $\begin{array}{c}\text { Non-Profit/Government } \\
\text { Eligible }\end{array}$ \\
\hline & (Corporate) & receive grants/funding from CEDF. & $\begin{array}{l}\text { (for systems } \\
\text { placed into } \\
\text { service on or } \\
\text { before } \\
12 / 31 / 2010 \text { ). }\end{array}$ & & \\
\hline
\end{tabular}

Source: Database of State Incentives for Renewable Energy and Efficiency $2010 \mathrm{~b}$

Please note: The information provided in this table presents an overview of state incentives, but it should not be used as the only source of information when making purchasing decisions, investment decisions, tax decisions or other binding agreements. For more information about individual programs listed above, visit the DSIRE Web site at http://www.dsireusa.org/. 
Table B-5. U.S. Department of Energy Brightfields Program Grants ${ }^{a}$

\begin{tabular}{|c|c|c|c|c|}
\hline $\begin{array}{l}\text { Award } \\
\text { Year }\end{array}$ & $\begin{array}{l}\text { Award } \\
\text { Amount }\end{array}$ & Project & Project Description & Project Status \\
\hline \multirow[t]{3}{*}{2000} & $\$ 30,000$ & $\begin{array}{l}\text { Brockton, MA: } \\
\text { Brownfields to } \\
\text { Brightfields Project }\end{array}$ & $\begin{array}{l}\text { "This project involved attracting a photovoltaic system manufacturer to a } \\
\text { Brockton Brownfield and building a solar array on a second site. } \\
\text { Anticipation: This array will bring into productive use up to } 27 \text { acres of } \\
\text { idle property and the array could also generate up to } 6 \mathrm{MW} \text { of electricity. } \\
\text { To create sufficient local demand to attract the manufacturer, other } \\
\text { potential sites for photovoltaic applications will be surveyed." }\end{array}$ & $\begin{array}{l}425-\mathrm{kW} \text { facility } \\
\text { commercially operation } \\
\text { since September } 27 \\
2006 \text {. Expanded by } 35 \\
\text { kW to } 460 \mathrm{~kW} \text { in July } \\
2007 ; \text { Grid-connected } \\
\text { selling } 100 \% \text { of output } \\
\text { into New England Power } \\
\text { Pool }\end{array}$ \\
\hline & $\$ 50,000$ & $\begin{array}{l}\text { Atlantic City, NJ: } \\
\text { Cityscape Solar- } \\
\text { Powered Bed and } \\
\text { Breakfast on and } \\
\text { Urban Brownfield. }\end{array}$ & $\begin{array}{l}\text { "Involves the construction of a solar powered bed and breakfast on an } \\
\text { urban Brownfield site in Atlantic City, New Jersey as part of an overall } \\
\text { neighborhood redevelopment plan with a sustainability theme. The } \\
\text { project will showcase the use of photovoltaics in supplying renewable } \\
\text { energy and also contain sustainable features such as recycled building } \\
\text { materials and Energy Star appliances, and will be located in the } \\
\text { "Cityscape Neighborhood," an area designed to promote renewable } \\
\text { energy, sustainable building materials, and concepts of New Urbanism." }\end{array}$ & Project canceled \\
\hline & $\$ 50,000$ & $\begin{array}{l}\text { Hanford, WA: } \\
\text { Brightfield Project }\end{array}$ & $\begin{array}{l}\text { "This project will ultimately be the largest photovoltaic installation of its } \\
\text { kind, and will bring the Brightfield concept to one of the worst Super } \\
\text { Fund sites in the nation. The funding provided will cover a portion of the } \\
\text { pilot phase of the project, involving } 40 \mathrm{~kW} \text {. Later phases will use a } \\
\text { wind/solar green energy blending strategy to finance development up to } \\
1 \mathrm{MW} \text { or larger. This solar array will act as a nucleation site around which } \\
\text { Energy Northwest intends to grow a renewable energy industrial park." }\end{array}$ & $\begin{array}{l}\text { 38.7-kW system installed } \\
\text { in May } 2002\end{array}$ \\
\hline \multirow[t]{2}{*}{2004} & $\$ 65,400$ & $\begin{array}{l}\text { Cedar Rapids, IA: } \\
\text { Bohemian } \\
\text { Commercial Historic } \\
\text { District Solar } \\
\text { Development } \\
\text { Program }\end{array}$ & $\begin{array}{l}\text { "The lowa Department of Natural Resources (IDNR) will partner with the } \\
\text { City of Cedar Rapids, the lowa Renewable Energy Association, Alliant } \\
\text { Energy, and Thorland Company to install a 7200-Watt solar array in } \\
\text { Cedar Rapids on a multiuse converted former warehouse building in a } \\
\text { designated Brownfields redevelopment area."The IDNR has established } \\
\text { partnerships with the City of Cedar Rapids, Alliant Energy, the lowa } \\
\text { Renewable Energy Association, and the building owner to increase the } \\
\text { economic and environmental viability of a redeveloped Brownfield area } \\
\text { and expand the value and viability of solar projects." }\end{array}$ & $7.2 \mathrm{~kW}$ installed \\
\hline & $\$ 59,400$ & Brockton, MA: Solar & “The City of Brockton will build New England's largest solar array at a & 425-kW facility \\
\hline
\end{tabular}


Energy Park:

Deploying a Solar

Array on a Brownfield

$\$ 125,000$ Raleigh, NC: Brightfield Technology Demonstration at NCSU remediated 27-acre Brownfield site in fall 2004. The 500-kilowatt (kW) solar photovoltaic (PV) array — or "Brightfield" — will be installed in an urban park setting with interpretive displays. The Brightfield could include as many as 6,720 solar panels connected in strings that span the site. The Brightfield will grow incrementally to $1 \mathrm{MW}$ with expansions financed through positive annual cash flow generated by the sale of renewable energy certificates (RECs) and electricity."

"Carolina Green Energy, LLC proposes to partner with the North Carolina Solar Center to design and install a 30-kW grid-tied photovoltaic (PV) system. As part of its continued efforts to bolster support for renewable energy, the Solar Center will incorporate the "Brownfield to Brightfield" project at Lot 86 into its ongoing education and outreach programs."

Source: U.S. Department of Energy State Energy Program 2006

According to EPA, the term brightfields refers to "the conversion of contaminated sites into usable land by bringing pollution-free solar energy and high-tech solar manufacturing jobs to these sites, including the placement of photovoltaic arrays that can reduce cleanup costs, building integrated solar energy systems as part of redevelopment, and solar manufacturing plants on brownfields." For more information, see http://epa.gov/ brownfields/partners/brightfd.htm. 
Table B-6. State Policy and Incentive Comparisons: Massachusetts, North Carolina, and Colorado

\begin{tabular}{|c|c|c|}
\hline \multicolumn{3}{|l|}{ MASSACHUSETTS } \\
\hline Incentive & Specifics & Sector \\
\hline $\begin{array}{l}\text { New Generation Energy - Community } \\
\text { Solar Lending Program }\end{array}$ & $\$ 5,000-\$ 100,000$ & Private \\
\hline $\begin{array}{l}\text { Massachusetts DOER - Solar } \\
\text { Renewable Energy Credits (SRECs) }\end{array}$ & $\$ 300-\$ 600$ (per MWh) & Both \\
\hline $\begin{array}{l}\text { Mass Energy Consumers Alliance - } \\
\text { Renewable Energy Certificate Incentive }\end{array}$ & & Both \\
\hline $\begin{array}{l}\text { Renewable Energy Property Tax } \\
\text { Exemption }\end{array}$ & $100 \%$ exemption for 20 years & Private \\
\hline CEC - Commonwealth Solar II Rebates & $\begin{array}{l}\$ 5,500 \text { (per host customer), up to } \\
\$ 250,000 \text { per parent company }\end{array}$ & Both \\
\hline CEC - Commonwealth Solar Stimulus & $\begin{array}{l}\$ 162,500 \text { per project (up to } \$ 1 \text { million } \\
\text { for any host customer entity, or parent } \\
\text { company/organization) }\end{array}$ & Both \\
\hline Policy & Specifics & Sector \\
\hline Massachusetts - Net Metering & & Both \\
\hline Renewable Energy Trust Fund & Public Benefit Fund & Private \\
\hline Renewable Portfolio Standard & $\begin{array}{l}\text { In-state PV: Mandated Target of } 400 \\
\text { MW }\end{array}$ & \\
\hline \multicolumn{3}{|l|}{ NORTH CAROLINA } \\
\hline Incentive & Specifics & Sector \\
\hline $\begin{array}{l}\text { Renewable Energy Tax Credit } \\
\text { (Corporate) }\end{array}$ & 35\% / \$2.5 million per installation & Private \\
\hline $\begin{array}{l}\text { Local Option - Revolving Loan Program } \\
\text { for Renewable Energy and Energy } \\
\text { Efficiency }\end{array}$ & Interest rate can be no more than $8 \%$ & Private \\
\hline Local Option - Clean Energy Financing & Debt repaid via property assessment & Private \\
\hline $\begin{array}{l}\text { Renewable Energy Tax Credit } \\
\text { (Personal) }\end{array}$ & $35 \%$ / \$2.5 million per installation & Private \\
\hline NC GreenPower Production Incentive & $\begin{array}{l}\text { Payments contingent on program } \\
\text { success }\end{array}$ & Both \\
\hline $\begin{array}{l}\text { Progress Energy Carolinas - SunSense } \\
\text { Commercial PV Incentive Program }\end{array}$ & $\$ 0.18 / \mathrm{kWh}$ for 20 years & Both \\
\hline TVA - Generation Partners Program & $\begin{array}{l}\$ 1000 \text { plus } \$ 0.12 / \mathrm{kWh} \text { above the retail } \\
\text { rate for solar and } \$ 0.03 / \mathrm{kWh} \text { above the } \\
\text { retail rate for all other eligible } \\
\text { renewables }\end{array}$ & Private \\
\hline $\begin{array}{l}\text { Property Tax Abatement for Solar } \\
\text { Electric Systems }\end{array}$ & $80 \%$ of appraised value & Both \\
\hline North Carolina Green Business Fund & Grant varies & Both \\
\hline $\begin{array}{l}\text { Energy Improvement Loan Program } \\
\text { (EILP) }\end{array}$ & $\begin{array}{l}\text { State Loan Program } \$ 500,000 \\
\text { maximum }\end{array}$ & Both \\
\hline
\end{tabular}




\begin{tabular}{|c|c|c|}
\hline \multirow{2}{*}{\multicolumn{3}{|c|}{$\begin{array}{c}\text { Policy } \\
\text { North Carolina - Net Metering }\end{array}$}} \\
\hline & & \\
\hline $\begin{array}{l}\text { Renewable Energy and Energy } \\
\text { Efficiency Portfolio Standard }\end{array}$ & Solar: $0.2 \%$ by 2018 & \\
\hline \multicolumn{3}{|l|}{ COLORADO } \\
\hline Incentive & Specifics & Sector \\
\hline $\begin{array}{l}\text { Boulder County - ClimateSmart Loan } \\
\text { Program }\end{array}$ & Commercial: $\$ 3,000-\$ 210,000$ & Private \\
\hline $\begin{array}{l}\text { Local Option - Improvement Districts for } \\
\text { Energy Efficiency and Renewable } \\
\text { Energy Improvements }\end{array}$ & Debt repaid via property assessment & Both \\
\hline $\begin{array}{l}\text { Renewable Energy Property Tax } \\
\text { Assessment }\end{array}$ & Varies & Private \\
\hline $\begin{array}{l}\text { Boulder - Solar Sales and Use Tax } \\
\text { Rebate }\end{array}$ & $\begin{array}{l}15 \% \text { refund on sales and use tax for the } \\
\text { solar installation }\end{array}$ & Private \\
\hline $\begin{array}{l}\text { Local Option - Sales and Use Tax } \\
\text { Exemption for Renewable Energy } \\
\text { Systems }\end{array}$ & Varies & Private \\
\hline $\begin{array}{l}\text { Sales and Use Tax Exemption for } \\
\text { Renewable Energy Equipment }\end{array}$ & $100 \%$ & Both \\
\hline $\begin{array}{l}\text { New Energy Economic Development } \\
\text { Grant Program }\end{array}$ & Competitive grant, Recovery Act funded & Private \\
\hline Xcel Energy - SolarRewards Program & $\begin{array}{l}\text { \$2/W DC with a maximum rebate of } \\
\$ 200,000 ; \text { REC payments will step } \\
\text { down over time as certain MW levels } \\
\text { are reached for each system } \\
\text { classification. }\end{array}$ & Private \\
\hline Policy & Specifics & Sector \\
\hline Colorado - Net Metering & & Private \\
\hline $\begin{array}{l}\text { Mandatory Green Power Option for } \\
\text { Large Municipal Utilities }\end{array}$ & $\begin{array}{l}\text { Allows retail customers the choice of } \\
\text { supporting emerging renewable } \\
\text { technologies }\end{array}$ & Both \\
\hline Boulder - Climate Action Plan Fund & Public Benefits Fund & Private \\
\hline Renewable Energy Standard & $\begin{array}{l}\text { Solar-electric (IOUs only): } 4 \% \text { of annual } \\
\text { requirement }(0.8 \% \text { of sales in } 2020) \text {; } \\
\text { half of solar-electric requirement must } \\
\text { be located on-site at customers' } \\
\text { facilities }\end{array}$ & \\
\hline $\begin{array}{l}\text { Solar, Wind and Energy-Efficiency } \\
\text { Access Laws }\end{array}$ & & \\
\hline
\end{tabular}

Source: Database of State Incentives for Renewable Energy and Efficiency 2009 
Table B-7. Key Policy Comparison for Subject States

\begin{tabular}{|c|c|c|c|}
\hline RPS & Colorado & Massachusetts & North Carolina \\
\hline Policy In Place & Yes & Yes & Yes \\
\hline Effective Date & $12 / 1 / 04$ & $4 / 1 / 02$ & $2 / 29 / 08$ \\
\hline Targets & $\begin{array}{l}20 \% \text { by } 2020 \text {; Solar- } \\
\text { electric: } 4 \% \text { of } \\
\text { annual requirement }\end{array}$ & $\begin{array}{l}15 \% \text { by } 2020 \text { and an } \\
\text { additional } 1 \% \text { each year } \\
\text { thereafter; in-state PV } \\
\text { mandated target of } \\
400 \mathrm{MW}\end{array}$ & $\begin{array}{l}12.5 \% \text { of } 2020 \text { retail } \\
\text { electricity sales by } 2021 \\
\text { with } .2 \% \text { from solar }\end{array}$ \\
\hline PBF & Colorado & Massachusetts & North Carolina \\
\hline Policy In Place & City of Boulder Only & Yes & No \\
\hline Effective Date & $4 / 1 / 07$ & $3 / 1 / 98$ & $\mathrm{~N} / \mathrm{A}$ \\
\hline \multirow[t]{4}{*}{ Charge } & $\begin{array}{l}\text { Maximum tax rates } \\
\text { for electricity } \\
\text { customers: }\end{array}$ & $\begin{array}{l}\$ 0.0005 \text { per kilowatt-hour } \\
(0.5 \text { mill/kWh) in } 2003 \\
\text { and in each following }\end{array}$ & N/A \\
\hline & $\begin{array}{l}\text { Residential: } \\
\$ 0.0049 / \mathrm{kWh}\end{array}$ & year & \\
\hline & $\begin{array}{l}\text { Commercial: } \\
\$ 0.0009 / \mathrm{kWh}\end{array}$ & & \\
\hline & $\begin{array}{l}\text { Industrial: } \\
\$ 0.0003 / \mathrm{kWh}\end{array}$ & & \\
\hline NET METERING & Colorado & Massachusetts & North Carolina \\
\hline Policy In Place & Yes & Yes & Yes \\
\hline Effective Date & $7 / 2 / 06$ & 1982 & $10 / 20 / 05$ \\
\hline System Capacity & $\begin{array}{l}120 \% \text { of the } \\
\text { customer's average } \\
\text { annual consumption }\end{array}$ & $\begin{array}{l}2 \mathrm{MW} \text { for "Class III" } \\
\text { systems; } 1 \mathrm{MW} \text { for "Class } \\
\text { II" systems; } 60 \mathrm{~kW} \text { for } \\
\text { "Class I" systems }\end{array}$ & $1 \mathrm{MW}$ \\
\hline REC Ownership & $\begin{array}{l}\text { Customer owns } \\
\text { RECs (must be } \\
\text { relinquished to utility } \\
\text { for } 20 \text { years in } \\
\text { exchange for } \\
\text { incentives) }\end{array}$ & Customer owns RECs & $\begin{array}{l}\text { Utility owns RECs } \\
\text { (unless customer } \\
\text { chooses to net meter } \\
\text { under an unfavorable } \\
\text { demand tariff) }\end{array}$ \\
\hline \multirow{2}{*}{$\begin{array}{l}\text { TAX INCENTIVES } \\
\text { APPLICABLE TO PV }\end{array}$} & Colorado & Massachusetts & North Carolina \\
\hline & $\begin{array}{l}\text { Property-Amount } \\
\text { varies depending on } \\
\text { rate set annually by } \\
\text { the Division of } \\
\text { Property Taxation }\end{array}$ & $\begin{array}{l}\text { Property-100\% } \\
\text { exemption for } 20 \text { years }\end{array}$ & $\begin{array}{l}\text { Corporate } 35 \% \\
\text { Property }-85 \% \text { of } \\
\text { appraised value }\end{array}$ \\
\hline Effective Date & 2001 & 1984 & $\begin{array}{l}\text { Corporate } 1 / 1 / 09 \\
\text { Property } 7 / 1 / 08\end{array}$ \\
\hline
\end{tabular}

Source: Database of State Incentives for Renewable Energy and Efficiency 2010c 


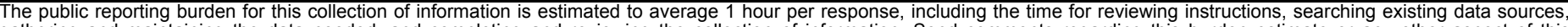

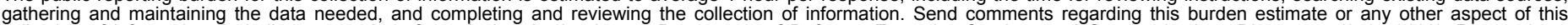

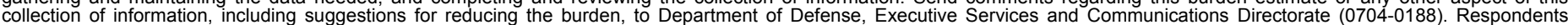

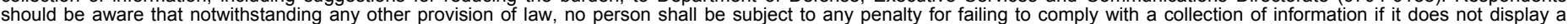

should be aware that notwithstanding

PLEASE DO NOT RETURN YOUR FORM TO THE ABOVE ORGANIZATION.

\begin{tabular}{l|l|l|}
\hline 1. REPORT DATE (DD-MM-YYYY) & 2. REPORT TYPE & 3. DATES COVERED (FrOm - TO)
\end{tabular}

August 2010

Technical Report

4. TITLE AND SUBTITLE

Feasibility Study of Economics and Performance of Solar

Photovoltaics in Nitro, West Virginia: A Study Prepared in

Partnership with the Environmental Protection Agency for the RE-

Powering America's Land Initiative: Siting Renewable Energy on

Potentially Contaminated Land and Mine Sites

5a. CONTRACT NUMBER

DE-AC36-08-GO28308

5b. GRANT NUMBER

5c. PROGRAM ELEMENT NUMBER

6. AUTHOR(S)

L. Lisell and G. Mosey

5d. PROJECT NUMBER

NREL/TP-6A2-48594

5e. TASK NUMBER

WFD3.1000

5f. WORK UNIT NUMBER
7. PERFORMING ORGANIZATION NAME(S) AND ADDRESS(ES)

National Renewable Energy Laboratory

1617 Cole Blvd.

Golden, CO 80401-3393

9. SPONSORING/MONITORING AGENCY NAME(S) AND ADDRESS(ES)
8. PERFORMING ORGANIZATION REPORT NUMBER

NREL/TP-6A2-48594
10. SPONSOR/MONITOR'S ACRONYM(S) NREL

11. SPONSORING/MONITORING AGENCY REPORT NUMBER

12. DISTRIBUTION AVAILABILITY STATEMENT

National Technical Information Service

U.S. Department of Commerce

5285 Port Royal Road

Springfield, VA 22161

13. SUPPLEMENTARY NOTES

14. ABSTRACT (Maximum 200 Words)

This report summarizes a feasibility study of solar photovoltaic (PV) installations on brownfields in or near the City of Nitro, West Virginia. The study was performed for the U.S. Environmental Protection Agency, in accordance with the RE-Powering America's Land initiative. The report includes estimates of the cost, performance, and site impacts of crystalline silicon (fixed axis), crystalline silicon (single axis tracking), and thin film (fixed axis) for eight sites in or near Nitro. The report also summarizes job creation if these sites were used for PV installations.

\section{SUBJECT TERMS}

solar photovoltaics; solar PV; crystalline silicon; thin film; brownfields; feasibility; Nitro, West Virginia; cost; system performance; economics; jobs; financing; electrical rates; impacts; EPA, RE-Powering America's Land

\begin{tabular}{|c|c|c|c|c|}
\hline \multicolumn{3}{|c|}{ 16. SECURITY CLASSIFICATION OF: } & \multirow{2}{*}{$\begin{array}{l}\text { 17. LIMITATION } \\
\text { OF ABSTRACT } \\
\text { UL }\end{array}$} & \multirow{2}{*}{$\begin{array}{l}\text { 18. NUMBER } \\
\text { OF PAGES }\end{array}$} \\
\hline $\begin{array}{l}\text { a. REPORT } \\
\text { Unclassified }\end{array}$ & $\begin{array}{l}\text { b. ABSTRACT } \\
\text { Unclassified }\end{array}$ & $\begin{array}{l}\text { c. THIS PAGE } \\
\text { Unclassified }\end{array}$ & & \\
\hline
\end{tabular}

9b. TELEPHONE NUMBER (Include area code) 